\title{
Sınıf Öğretmenlerinin İş Doyumu ve İş Yaşamındaki Yalnızlık Düzeylerinin İncelenmesi
}

\author{
İbrahim Gafa \\ Kırşehir Ahi Evran Üniversitesi, Sosyal Bilimler Enstitüsü, Yüksek Lisans Öğrencisi, Kırşehir \\ ibrahimgafa@gmail.com \\ ORCID ID: https://orcid.org/0000-0002-8044-3922
}

Yurdal Dikmenli

Kırşehir Ahi Evran Üniversitesi, Eğitim Fakültesi, Temel Eğitim Bölümü, Sınıf Eğitimi Anabilim Dalı, Kırşehir dikmenliy@hotmail.com

ORCID ID: https://orcid.org/0000-0003-3738-3095

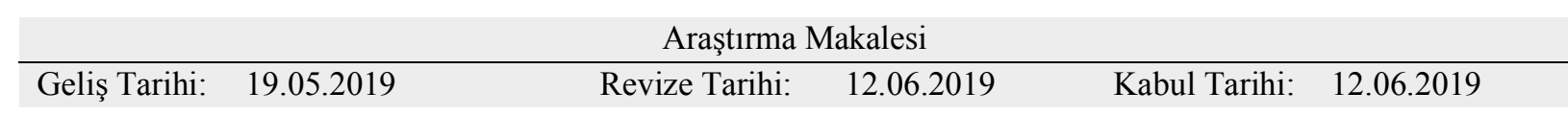

\section{Atıf Bilgisi}

Gafa, İ. ve Dikmenli, Y. (2019). Sınıf öğretmenlerinin iş doyumu ve iş yaşamındaki yalnızlık düzeylerinin incelenmesi, Ahi Evran Üniversitesi Sosyal Bilimler Enstitüsü Dergisi, 5(1), 131-150.

\section{ÖZ}

$\mathrm{Bu}$ çalışmanın temel amacı; Millî Eğitim Bakanlığına bağlı devlet okullarında görev yapan sınıf öğretmenlerinin iş doyumu ve iş yaşamındaki yalnızlık düzeylerinin incelenmesidir. Çalışmada ayrıca cinsiyet, medeni durum ve mesleki kıdem gibi çeşitli değişkenlerle iş doyumu ve iş yaşamında yalnızlık arasındaki ilişkiler incelenmiştir. Araştırma 2017-2018 eğitim-öğretim yılında Kırşehir ve Erzurum il merkezlerinde bulunan toplam 415 sınıf öğretmeniyle yürütülmüştür. İliş̧kisel tarama modelinde tasarlanmış araştırmada verilerin toplanması için Kişisel Bilgi Formu, Minnesota İş Doyum Ölçeği ve İş Yaşamında Yalnızlık Ölçeği kullanılmıştır. Elde edilen veriler paket veri programına girilerek üzerinde istatistiksel işlemler yapılmıştır. Araştırma kapsamında öğretmenlerin yüksek düzey iş doyumu ve içsel doyuma, orta düzey dışsal doyuma sahip oldukları tespit edilmiştir. İş doyumu ile cinsiyet, medeni durum ve mesleki kıdem değişkenleri arasında anlamlı bir farklılık olmadığı sonuçlarına ulaşılmıştır. Öğretmenlerin düşük düzey iş yaşamında yalnızlık, duygusal yoksunluk ve sosyal arkadaşlığa sahip oldukları tespit edilmiştir. İş yaşamında yalnızlık ile medeni durum arasında anlamlı bir farklılık olmadığı sonuçlarına ulaşılmıştır. Ancak öğretmenlerin cinsiyet ve mesleki kıdemlerinin yalnızlık düzeylerini ve alt boyutlarını istatistiksel olarak etkiledikleri tespit edilmiştir. Ayrıca sınıf öğretmenlerinin iş doyumu ile iş yaşamında yalnızlıkları arasında negatif yönde yüksek düzeyde ve istatistiksel açıdan anlamlı bir ilişki olduğu sonucuna ulaşılmıştır.

Anahtar Kelimeler: Sınıf öğretmeni, iş doyumu, iş yaşamında yalnızlık.

\section{An Investigation of Elementary Teachers' Job Satisfaction and Loneliness Levels in Work Life}

ABSTRACT

This study aimed to determine elementary teachers' job satisfaction and loneliness in workplace who work in public schools. Besides, influence of gender, marital status and teaching experience, on teachers' job satisfaction and loneliness in the workplace were investigated in this study. The study included 415 elementary teachers who work in public schools located in Kırşehir and Erzurum in the 2017-2018 educational year. Personal information form, Minnesota Job Satisfaction Scale, and Loneliness in the Workplace Scale were used to collect data in this casual-comparative survey research. The collected data were input in the data processing program and analyzed by using relevant statistical method. Results of the study showed that elementary teachers had high levels of job satisfaction and internal satisfaction, and middle level of external satisfaction. Besides, it was found that gender, marital status and teaching experience did not influence their job satisfaction. It was revealed that teachers had low level of loneliness in the workplace, emotional loneliness and social friendship. Marital status did not influence teachers' loneliness in the workplace. However, it was found that gender and teaching experience of teachers statistically influenced sub-dimensions and loneliness of teachers. Moreover, this study showed that there was a negative high correlation between job satisfaction and loneliness in the workplace of elementary teachers.

Keywords: Elementary teacher, job satisfaction, loneliness in the workplace. 


\section{Giriș}

Günümüz rekabet ortamında örgütlerin ayakta kalabilmesi, rekabet edebilmesi ve başarılı olabilmesi kaynaklarını etkili ve verimli bir şekilde kullanmasına bağlıdır. Örgütlerin en önemli kaynağı çalışanlarıdır ve örgütlerin başarısını arttıran unsurların başında çalışanların performansı gelmektedir (Akşit Aşık, 2010). Çalışanların iş yerlerindeki yaşantıları ve performansları çok önemlidir (Kağan, 2010). İnsanlar kendi ilgi ve yetenekleri doğrultusunda severek yapacakları bir iş seçmiş olsalar bile iş yerlerinde olumlu veya olumsuz birçok durumla karşılaşabilirler (Çetinkanat, 2000). İş yerlerindeki bu yaşantılar çalışanlara işleri ile ilgili çeşitli tecrübeler kazandırmanın yanı sıra çeşitli duygu ve tutumlarının oluşmasına da sebep olmaktadır. İş yerinde yaşanılan çeşitli olaylar neticesinde çalışanlarda oluşan üzüntü, sevinç, endişe, panik, zevk, içerleme ve utanma gibi duygular kişiler ve örgütler üzerinde etkili olabilmektedir (Sarıbay ve Sarıbay, 2016). Bireyler çalışma hayatında onaylanmak ve takdir edilmek isterler. Çalışanların beklentilerinin karşılanması hem çalıştığı iş yerinden memnun olmalarını hem de iş yerine olumlu yönde katkıda bulunmalarını sağlar (Aydın, Sarıer ve Uysal, 2013). Çalışanlar yaptıkları işten doyum sağladıkları takdirde daha sağlıklı ve yaşamlarının diğer alanlarında da daha mutlu olacakları düşünülmektedir (Özkalp ve Kırel, 2001; Özyürek, 2009).

Bütün bir toplumu etkileme özelliğine sahip olan öğretmenler, günlerinin büyük bir bölümünü okullarda geçirmektedirler (Yılmaz ve Boğa Ceylan, 2011). Öğretmenlerin duyguları, coşkuları, heyecanları ve moralleri okullardaki performansı için büyük önem taşımaktadır (Karaköse ve Kocabaş, 2006). Çünkü geleceğin kaliteli insan gücünü yetiştiren okullarda istenilen nitelikte bireyler yetiştirebilmenin ön koşulu öğrencileri yetiştiren öğretmenlerin iş doyumunun sağlamasından geçmektedir (Filiz, 2014).

İş doyumu kavramı genel olarak 1920'li yıllarda ortaya çıkmış ve bugüne kadar pek çok tanımı yapılmıştır. Bir kavram olarak iş doyumu çalışanın işine karşı tutumu ve işin özellikleriyle çalışanın istekleri birbirine uyum sağladığı zaman gerçekleşir (Silah, 2002). İş doyumunun bireyin ruh, beden sağlığ1 ve kişinin üretkenliğini etkilediği bilinmektedir (Akşit Aşık, 2010). Yetersiz iş doyumu çalışanın psikolojik olgunluğa erişmesini zorlaştırarak hayal kırıklığına uğramasına, çalışanın veriminin ve performansının düşmesine neden olabilmektedir (Bozkurt ve Bozkurt, 2008).

İş yerlerindeki kötü çalışma koşulları çalışanları, negatif yönde etkileyerek olumsuz davranışlarda bulunmalarına ve hizmet alan kişileri de olumsuzluğa sevk etmektedir (Aktaş, 2001). Günlük yaşamlarının büyük bölümünü iş yerinde geçiren bireyler, değişen rekabet koşulları ve gelişen teknoloji sebebiyle çalışma ortamlarında yalnızlık hissi de yaşayabilmektedirler. Evrensel bir yaşam tecrübesi olan yalnızlık, kişinin arzu ettiği sosyal ilişki düzeyine erişememesi nedeniyle maruz kaldığı, rahatsızlık veren psikolojik bir durum olarak tanımlanmaktadır (Demirbaş ve Haşit 2016). Bireyin yaşadığı yalnızlığın iş hayatındaki boyutu ise iş yaşamında yalnızlık şeklinde gerçekleşmektedir (Keser ve Karaduman, 2014). İş yaşamında yalnızlık normal yalnızlıktan farklı olarak, günlük yaşamda kendisini yalnız hissetmeyen, çevresiyle sağlıklı ilişkiler kurabilen, mutlu olan bireyin; iş yaşamında yaşadığ 1 problemlere bağlı olarak kendisini yalnız hissetmesidir (Mercan, Demirci, Özler ve Oyur, 2015). Sosyolojik psikolojik ve fiziksel olarak yalnızlık hissine kapılan bireyden, olumlu tutum ve davranış beklenemez (Yurcu ve Kocakula, 2015). Bireylerin iş ortamına ve yaptığı işe karşı olan tutum ve davranışları bireysel ve sosyal yaşamlarına da yansımaktadır. Çünkü insan günlük hayatının önemli bir bölümünü iş yerinde çalışarak geçirmektedir (İşcan ve Sayın, 2010; Demir, 2011). İş yaşamında yaşanan yalnızlığın, olumsuz etkilerinin başında iş doyumsuzluğu ve stres gelmektedir. Çeşitli nedenlerle yaşanan iş yaşamında yalnızlık algısının, öğretmenleri de etkilediği düşünülmektedir (Keser ve Karaduman, 2014).

İnsanlarla doğrudan iletişim içinde olan öğretmenin okul ortamındaki etkileşimi çok önemlidir. Davranışları, tutumları ve tepkileriyle bireyleri etkileyerek insanların davranışlarının düzenlenmesinde etkili olan öğretmenlerin diğer öğretmenlerle olan sosyal etkileşimlerinin, çalışma yaşamına katkı sağlayacağ1 düşünülmektedir (Oğuz ve Kalkan, 2014; Yakut ve Certel, 2016). Aynı zamanda öğretmenlerin iş yerlerinde yalnızlık düzeylerinin azalması, okullarda eğitim ve öğretim faaliyetlerinin 
daha kaliteli olmasına, başarının artmasına ve iyi bir okul ortamının oluşmasına katkı sağlayacağı düşünülmektedir (Çifçi ve Dikmenli, 2015). Öğretmenler okulda kendilerini yalnız hissetmez ve kendilerini çalıştığ 1 okulun bir parçası olarak görürlerse daha verimli ve sağlıklı çalışabilirler (Nartgün ve Demirer, 2016). Çünkü okullarda öğretmenlerin yaşadığı yalnızlık problemi sadece kendi yaşamıyla sınırlı kalmayarak olumsuz etkisi toplumu da yansıyacaktır (Yakut ve Certel, 2016).

Literatür incelendiğinde sınıf öğretmenlerinin iş doyumu ve iş yaşamında yalnızlıklarına yönelik ayrı ayrı çalışmalar yapılsa da bu iki kavramı birlikte inceleyen çalışmaya rastlanmamıştır. $\mathrm{Bu}$ çalışmanın amacı ilkokullarda görev yapan sınıf öğretmenlerinin iş doyumlarını ve iş yaşamında yalnızlık düzeylerini farklı değişkenlere göre tespit etmek ve aralarındaki ilişkiyi belirlemektir.

Araştırma kapsamında sınıf öğretmenlerinin iş doyumu ve iş yaşamında yalnızlık düzeylerinin belirlenmesi, iş doyumunu artırmaya ve iş yaşamında yalnızlığı azaltmaya yönelik tedbirlerin alınmasına katkı sağlayacağı düşünülmektedir. Çalışanlar için olumsuz durumlar olan iş doyumsuzluğunun ve iş yaşamında yalnızlı̆̆ın ele alınarak öğretmenlerin lehine kullanılabilmesine yönelik getirilen öneriler ile sonraki çalışmalara destek olması ve rehberlik etmesi açısından bu çalışma önemli bulunmuştur.

\section{Yöntem}

$\mathrm{Bu}$ araştırma nicel araştırma olup, ilişkisel tarama modeli kullanılmıştır. İlişkisel tarama modelinde, iki veya daha çok değişken arasında değişimin varlığı ve derecesi belirlenmeye çalışı1ır (Karasar, 2005). Bu doğrultuda, sınıf öğretmenlerinin iş doyumu ve iş yaşamında yalnızlık düzeyleri betimlenmeye çalışılmıştır. Daha sonra da iş doyumu ve iş yaşamı arasındaki ilişki incelenmiştir.

\section{Araştırmanın Evren ve Örneklemi}

Araştırmanın ulaşılabilir evrenini Kırşehir ve Erzurum illerinde görev yapan 6433 sınıf öğretmeni oluşturmaktadır. Araştırmanın örneklemini, 2017-2018 eğitim-öğretim yılında, Millî Eğitim Bakanlığına bağlı ilkokullarda görev yapan 415 sınıf öğretmeni oluşturmaktadır. Araştırma grubunda yer alan öğretmenlere kolay ulaşmak amaciyla uygun örnekleme yöntemi seçilmiştir. Kazara örnekleme yöntemi zaman, para ve işgücü sınırlılıkları nedeniyle örneklemin kolay ulaşılabilir ve uygulama yapılabilir birimlerden seçilmesidir (Balc1, 2011). 650 öğretmene ulaşılmış ancak gönüllülük esas olduğu için katılmak istemeyen sınıf öğretmenleri dâhil edilmemiştir. Bu nedenle, araştırmaya Kırşehir'den 210, Erzurum'dan 205 sınıf öğretmeni katılmıştır. Çalışmada bağımsız değişken olarak öğretmenlerin cinsiyeti, medeni durumları, mesleki kıdemleri ve eğitim düzeyleri alınmıştır. Örneklemde yer alan ögrretmenlerin kişisel özellikleri Tablo 1'de verilmiştir.

Tablo 1

Örneklemin Kişisel Özellikleri

\begin{tabular}{llcc}
\hline \multirow{2}{*}{ Değişkenler } & Değişken Düzeyi & $\mathrm{n}$ & $\%$ \\
\hline \multirow{2}{*}{ Cinsiyet } & Kadın & 190 & 45,8 \\
\cline { 2 - 4 } & Erkek & 225 & 54,2 \\
\hline \multirow{2}{*}{ Medeni Durum } & Evli & 361 & 87,0 \\
\cline { 2 - 4 } & Bekâr & 54 & 13,0 \\
\hline \multirow{4}{*}{ Mesleki Kıdem } & $1-5$ yıl & 39 & 9,4 \\
\cline { 2 - 4 } & $6-10$ yıl & 70 & 16,9 \\
\cline { 2 - 4 } & $11-15$ yıl & 69 & 16,6 \\
\cline { 2 - 4 } & $16-20$ yıl & 56 & 13,5 \\
\cline { 2 - 4 } & $21-25$ yıl & 62 & 119 \\
\cline { 2 - 4 } & 26 yll ve üzeri & & 28,7 \\
\hline
\end{tabular}


Tablo 1 incelendiğinde, araştırmaya katılan sınıf öğretmenlerinin \%45,8'i kadın, \%54,2'si erkektir. Öğretmenlerin \%87'si evli, \%13'ü ise bekârdır. Öğretmenlerin \%9,4'ü 1-5 yıl mesleki kıdeme, \%16,9'u 6-10 yıl mesleki kıdeme, \%16,6's1 11-15 y1l mesleki kıdeme, \%13,5'i 16-20 yıl mesleki k1deme, \%14,9'u 21-25 yıl mesleki k1deme ve \%28,7'si ise 26 yıl ve üzeri mesleki kıdeme sahiptir.

\section{Veri Toplama Araçları}

Araştırmada, sınıf öğretmenlerinin kişisel özellikleri hakkında bilgi almak için "Kişisel Bilgi Formu", sınıf öğretmenlerinin iş doyum düzeylerini araştırmak için "Minnesota İş Doyum Ölçeği" ve iş yaşamındaki yalnızlıklarını araştırmak için "İş Yaşamında Yalnızlık Ölçeği”" kullanılmıştır.

\section{Kişisel Bilgi Formu}

Kişisel Bilgi Formu, araştırma problemi kapsamında önem taşıyan, sınıf öğretmenlerine ait kişisel özellikleri tespit edebilmek üzere araştırmacı tarafindan hazırlanan toplam 5 maddeden oluşan bir formdur. Kişisel bilgi formuyla sınıf öğretmenlerinin cinsiyeti, medeni durumu, mesleki kıdemi, eğitim düzeyi ve okuttuğu sınıf düzeyleri sorgulanmıştır.

\section{Minnesota İş Doyum Ölçeği}

Sınıf öğretmenlerinin iş doyum düzeylerini tespit etmek amacıyla daha önce iş doyumu ile ilgili pek çok araştırmada kullanılan Minnesota İş Doyum Ölçeği (MiDÖ) kullanılmıştır. Ölçek, Weiss, Davis, England ve Andlofquist tarafından 1967 yılında geliştirilmiş olup Baycan (1985) tarafindan Türkçeye çevrilip geçerlilik ve güvenirlilik çalışması yapılmıştır. Çevrilen ölçeğin güvenirliği incelendiğinde Cronbach Alpha değeri 0,77 olarak belirlenmiştir. Ölçek 5'li likert tipi 20 maddeden oluşmaktadır. Maddeler "Hiç Memnun Değilim" 1 puan, "Memnun Değilim" 2 puan, "Karasızım" 3 puan, "Memnunum" 4 puan, "Çok Memnunun" 5 puan şeklinde derecelendirilmiştir. Ölçeğin içsel doyum $(1,2,3,4,7,8,9,10,11,15,16,20$.) ve dişsal doyum $(5,6,12,13,14,17,18,19$.) olmak üzere iki alt boyutu bulunmaktadır. İçsel doyum yapılan işin ilgi ve yeteneklere uygun olması, yaratıcılığa olanak vermesi; dışsal doyum ise çalışma ortamı, iş arkadaşları, yönetim ve ücret gibi faktörleri kapsar. Her bir madde bireyin memnun olma derecelerini ölçmektedir.

\section{İş Yaşamında Yalnızlık Ölçeği}

Wright (2005) tarafindan geliştirilen İş Yaşamında Yalnızlık Ölçeği (IYYOÖ), Doğan, Çetin ve Sungur (2009) tarafindan Türkçeye çevrilerek geçerlilik ve güvenirlilik çalışması yapılmıştır. Güvenirlik için iç tutarlılık katsayısı hesaplanan ölçeğin Cronbach Alpha değeri 0,90 olarak hesaplanmıştır. Araştırmada kullanılan 16 maddeden oluşan, 5'li Likert tipi ölçek iki alt boyuttan oluşmaktadır. İlk 9 madde çalışanların duygusal yoksunluğunu (1, 2, 3, 4, 5, 6, 7, 8, 9. maddeler); son 7 madde ise ve sosyal arkadaşlık $(10,11,12,13,14,15,16$. maddeler) boyutunu ölçmektedir. Ayrıca ölçeğin $(5,6,10,11,12,14,15$ ve 16 . maddeler) 8 olumsuz maddesi bulunmaktadır. IYYYÖ'nün puanlamasında, "Hiçbir Zaman" 1 puan, "Nadiren" 2 puan, "Bazen" 3 puan, "Genellikle" 4 puan, "Her zaman" 5 puan olarak derecelendirilmiştir.

\section{Verilerin Analizi}

Elde edilen veriler paket veri programında analiz edilmiştir. Verilerin temel istatistiksel analizleri yapılmadan önce, verilerin normal dağılıp dağılmadığı ve varyansların homojenliği incelenmiştir. Normal dağılım gösteren bağımsız iki örneklem grubuna ilişkin ortalamalar arası farkı belirlemek için bağımsız örneklemler için t testi, ikiden fazla grup arasındaki farkı belirlemek için ANOVA testi (tek yönlü varyans analizi); normal dağılım göstermeyen bağımsız iki örneklem grubuna ilişkin ortalamalar arası farkı belirlemek için Mann-Whitney U testi, ikiden fazla grup arasındaki farkı belirlemek için ise Kruskal Wallis-H testi kullanılmıştır. Ayrıca Pearson Korelasyon analizi yapılarak 
değişkenler arasında ilişki olup olmadığı, varsa bu ilişkinin yönü ve şiddeti belirlenmiştir. Analizlerde anlamlılık düzeyi $\mathrm{p}<0,05$ olarak kabul edilmiştir.

Minnesota İş Doyum Ölçeği'nin puanlamasında, "Hiç Memnun değilim" 1 puan, "Biraz meтnипит" 2 puan, "Orta düzeyde memnunum" 3 puan, "Memnunum" 4 puan, "Çok memnunum" 5 puan olarak değerlendirilmiştir. Ölçekte olumsuz ifade olmadığı için ters puanlanan madde bulunmamaktadır. Ölçekten alınan yüksek puanlar iş doyumunda memnuniyeti gösterirken, ölçekten alınan düşük puanlar iş doyumundaki memnuniyetsizliği göstermektedir.

Ölçeğin tümü için güvenirlik katsayısı Cronbach Alpha. 92, içsel doyum alt boyutu için. 90 ve dışsal doyum alt boyutu için. 86'dır. Ölçeğin tümü için alınabilecek puan 20-100 arasında değişmekte ve yükssek puanlar artan iş doyumunu göstermektedir. Ölçeğin alt boyutları ile ilgili bilgiler tabloda sunulmuştur.

Tablo 2

Sınıf Öğretmenlerinin İş Doyum Düzeylerinin Alt Boyutlarının Belirlenmesinde Kullanılan Minimum ve Maksimum Puanlar

\begin{tabular}{lccc}
\hline İș Doyumu Alt Boyutları & Madde Sayısı & Minimum Puan & Maksimum Puan \\
\hline İçsel Doyum & 12 & 12 & 60 \\
\hline Dişsal doyum & 8 & 8 & 40 \\
\hline Toplam & 20 & 20 & 100 \\
\hline
\end{tabular}

Tablo 2'de görüldüğü üzere MiDÖ'nun tamamından alınabilecek puanlar 20 ile 100; içsel doyum alt boyutu puanları 12 ile 60 ve dişsal doyum alt boyutu puanları ise 8 ile 40 puan arasında değişmektedir. Ölçekten alınan yüksek puanlar artan iş doyumunu gösterirken, ölçekten alınan düşük puanlar ise iş doyumunun düşük düzeyde olduğunu göstermektedir.

İş Yaşamında Yalnızlık Ölçeğinin puanlamasında, "Hiçbir zaman" 1 puan, "Nadiren" 2 puan, "Bazen" 3 puan, "Genellikle" 4 puan, "Her zaman" 5 puan olarak değerlendirilmiştir. 8 ters maddesi $(5,6,10,11,12,14,15$ ve 16 . maddeler) bulunan ölçekte bu sorular tersten kodlama yapılarak analiz gerçekleştirilmiştir.

Ölçeğin tümü için güvenirlik katsayısı Cronbach Alpha. 92, duygusal yoksunluk alt boyutu için. 89 ve sosyal arkadaşlık alt boyutu için. $87^{\prime}$ dir. Ölçeğin tümü için alınabilecek puan 16-80 arasında değişmekte ve yüksek puanlar iş yaşamında artan yalnızlığı göstermektedir. Ölçeğin alt boyutları ile ilgili bilgiler tabloda sunulmuştur.

Tablo 3

Sınıf Öğretmenlerinin Işs Yaşamında Yalnızlık Düzeylerinin Alt Boyutlarının Belirlenmesinde Kullanılan Minimum ve Maksimum Puanlar

\begin{tabular}{lccc}
\hline İş Yaşamında Yalnızlık Alt Düzeyleri & Madde Sayısı & Minimum Puan & Maksimum Puan \\
\hline Duygusal Yoksunluk & 9 & 9 & 45 \\
\hline Sosyal Arkadaşlık & 7 & 7 & 35 \\
\hline Toplam & 16 & 16 & 80 \\
\hline
\end{tabular}

Tablo 3'te görüldüğü üzere IYYYÖ’nün tamamından alınabilecek puanlar 16 ile 80; Duygusal Yoksunluk alt boyutu puanları 9 ile 45 ve Sosyal Arkadaşlık alt boyutu puanları ise 7 ile 35 puan arasında değişmektedir. Ölçekten alınan yüksek puanlar iş yaşamında artan yalnızlı̆̆ı, ölçekten alınan düşük puanlar iş yaşamında yaşanan yalnızlığın düşük düzeyde olduğunu göstermektedir.

\section{Bulgular}

Bu bölümde, "Minnesota İş Doyum Ölçeği” ve "İş Yaşamında Yalnızlık Ölçeği” ile sınıf öğretmenlerinden toplanan verilerin çözümlenmesinden elde edilen bulgulara yer verilmiştir. 


\section{Sınıf Öğretmenlerinin İş Doyumu Düzeyleri ile İlgili Bulgular}

Sınıf öğretmenlerinin iş doyumu düzeyleri Tablo 4'te sunulmaktadır.

Tablo 4

Sinıf Öğretmenlerinin İ̧̧ Doyumu Düzeyleri

\begin{tabular}{|c|c|c|c|c|c|c|c|c|c|}
\hline & $\begin{array}{l}\text { Alt } \\
\text { Boyutlar }\end{array}$ & & Düşük & Orta & Yüksek & Min. & Mak. & $\overline{\mathrm{x}}$ & $\mathrm{S}$ \\
\hline \multirow{9}{*}{ 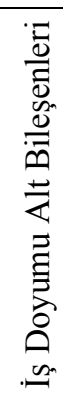 } & \multirow{3}{*}{$\begin{array}{l}\text { İçsel } \\
\text { Doyum }\end{array}$} & Aralık & $12-27$ & $28-43$ & $44-60$ & \multirow{3}{*}{21} & \multirow{3}{*}{60} & \multirow{3}{*}{47,7518} & \multirow{3}{*}{7,66815} \\
\hline & & $\mathrm{f}$ & 10 & 81 & 324 & & & & \\
\hline & & $\%$ & 2,4 & 19,5 & 78,1 & & & & \\
\hline & \multirow{3}{*}{$\begin{array}{l}\text { Dişsal } \\
\text { Doyum }\end{array}$} & Aralık & 8-18 & 19-29 & $30-40$ & \multirow{3}{*}{11} & \multirow{3}{*}{40} & \multirow{3}{*}{28,9205} & \multirow{3}{*}{6,21133} \\
\hline & & $\mathrm{f}$ & 34 & 155 & 226 & & & & \\
\hline & & $\%$ & 8,2 & 37,3 & 54,5 & & & & \\
\hline & \multirow{3}{*}{ Toplam } & Aralık & $20-47$ & $48-75$ & $76-100$ & \multirow{3}{*}{34} & \multirow{3}{*}{100} & \multirow{3}{*}{76,6723} & \multirow{3}{*}{12,70793} \\
\hline & & $\mathrm{f}$ & 11 & 154 & 250 & & & & \\
\hline & & $\%$ & 2,7 & 37,1 & 60,2 & & & & \\
\hline
\end{tabular}

Tablo 4’te görüldüğü gibi sınıf öğretmenlerinin içsel doyum alt puanları 21 ile 60 arasında değişmektedir. İ̧̧sel doyum düzeyine ait veriler incelendiğinde sınıf öğretmenlerinin \%2,4'ünün düşük düzey içsel doyuma, \%19,5'nin orta düzey içsel doyuma ve \%78,1'nin ise yüksek düzey içsel doyuma sahip oldukları görülmektedir. Sınıf öğretmenlerinin içsel doyum ortalamaları ise $\overline{\mathrm{X}}=47,75$ ile yüksek düzey doyuma sahip oldukları söylenebilir.

Sınıf öğretmenlerinin dışsal doyum alt boyutu puanları 11 ile 40 arasında değişmektedir. Dışsal doyum düzeyine ait veriler incelendiğinde sınıf öğretmenlerinin $\% 8,2$ 'sinin düşük düzey dışsal doyuma, \%37,3'nün orta düzey dışsal doyuma ve \%54,5'inin ise yüksek düzey dışsal doyuma sahip oldukları görülmektedir. Sınıf öğretmenlerinin dışsal doyum ortalamaları ise $\overline{\mathrm{X}}=28,92$ ile orta düzey doyuma sahip oldukları söylenebilir.

Sınıf öğretmenlerinin iş doyum toplam puanları 34 ile 100 arasında değişmekte; ortalaması ise 79,67'dir. İş doyumu düzeyine ait veriler incelendiğinde sınıf öğretmenlerinin \%2,7'sinin düşük düzey iş doyumuna, \%37,1'inin orta düzey iş doyumuna ve \%60,2'sinin ise yüksek düzey iş doyumuna sahip oldukları görülmektedir. Sınıf öğretmenlerinin iş doyum ortalamalarına bakıldığında ise $\overline{\mathrm{X}}=76,67$ ile yüksek düzey doyuma sahip oldukları söylenebilir.

Sınıf öğretmenlerinin iş doyumu düzeylerinin cinsiyete göre farklılığı mann-whitney u testi analizi Tablo 5'te sunulmaktadır.

Tablo 5

Sinıf Öğretmenlerinin İş Doyumu Düzeylerinin Cinsiyete Göre Farklılı̆̆ Mann-Whitney U Testi Analizi

\begin{tabular}{|c|c|c|c|c|c|c|c|}
\hline & & Cinsiyet & $\mathrm{n}$ & $\begin{array}{c}\text { Sira } \\
\text { Ortalamas1 } \\
\end{array}$ & $\begin{array}{c}\text { Sira } \\
\text { Toplamı } \\
\end{array}$ & $\mathrm{U}$ & $\mathrm{p}$ \\
\hline \multirow{6}{*}{ 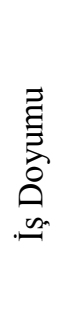 } & \multirow{2}{*}{ İçsel Doyum } & Kadın & 190 & 215,53 & 40951,00 & \multirow{2}{*}{19944,00} & \multirow{2}{*}{,239 } \\
\hline & & Erkek & 225 & 201,64 & 45369,00 & & \\
\hline & \multirow{2}{*}{ Dışsal Doyum } & Kadın & 190 & 206,59 & 39252,00 & \multirow{2}{*}{21107,00} & \multirow{2}{*}{, 825} \\
\hline & & Erkek & 225 & 209,19 & 47068,00 & & \\
\hline & \multirow{2}{*}{$\begin{array}{l}\text { İş Doyumu } \\
\text { Toplam }\end{array}$} & Kadın & 190 & 210,16 & 39930,00 & \multirow{2}{*}{20965,00} & \multirow{2}{*}{, 736} \\
\hline & & Erkek & 225 & 206,18 & 46390,00 & & \\
\hline
\end{tabular}


Tablo 5 incelendiğinde sınıf öğretmenlerinin cinsiyetlerinin iş doyum alt boyutu olan içsel doyum puanları üzerine etkisini incelemek amacıyla yapılan Mann-Whitney U Testi sonucuna göre $(\mathrm{U}=19944,000 ; \mathrm{p}>0,05)$ kadın öğretmenler ile erkek öğretmenler arasında istatistiksel olarak anlamlı fark olmadığı görülmüştür. Bu sonuçlara göre cinsiyetin sınıf öğretmenlerinin içsel doyum puanları üzerinde etkisi olmadığı söylenebilir.

Sınıf öğretmenlerinin cinsiyetlerinin iş doyumu alt boyutu olan dışsal doyum puanlarına göre $(U=21107,000 ; p>0,05)$ kadın ve erkek öğretmenler arasında istatistiksel olarak anlamlı fark olmadığ görülmüştür. Bu sonuçlara göre cinsiyetin sınıf öğretmenlerinin dışsal doyum puanları üzerinde etkisi olmadığı görülmüştür.

Sınıf öğretmenlerinin cinsiyetlerinin iş doyumu toplam puanlarına göre (U=20965,000; p>0,05) kadın ile erkek öğretmenler arasında istatistiksel olarak anlamlı fark olmadığı görülmüştür. Bu sonuçlara göre cinsiyetin sınıf öğretmenlerinin toplam iş doyum puanları üzerinde etkisi olmadığı bulgusuna ulaşılmıştır.

Sınıf öğretmenlerinin iş doyumu puanlarının medeni durumlarına göre farklılığı $\mathrm{t}$ testi analizi Tablo 6'da sunulmaktadir.

Tablo 6

Sını Öğretmenlerinin İş Doyumu Puanlarının Medeni Durumlarına Göre Farklılığı t Testi Analizi

\begin{tabular}{|c|c|c|c|c|c|c|c|c|}
\hline & & $\begin{array}{l}\text { Medeni } \\
\text { Durum }\end{array}$ & $\mathrm{n}$ & $\bar{X}$ & SS & $\mathrm{Sd}$ & $\mathrm{t}$ & $\mathrm{p}$ \\
\hline \multirow{6}{*}{ 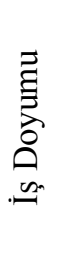 } & \multirow{2}{*}{ İçsel Doyum } & Evli & 361 & 47,6150 & 7,65715 & \multirow{6}{*}{413} & \multirow{2}{*}{,- 940} & \multirow{2}{*}{,348 } \\
\hline & & Bekâr & 54 & 48,6667 & 7,75084 & & & \\
\hline & \multirow{2}{*}{ Dişsal Doyum } & Evli & 361 & 28,8920 & 6,19785 & & \multirow{2}{*}{,- 242} & \multirow{2}{*}{, 809} \\
\hline & & Bekâr & 54 & 29,1111 & 6,35630 & & & \\
\hline & \multirow{2}{*}{$\begin{array}{l}\text { İş Doyum } \\
\text { Toplam }\end{array}$} & Evli & 361 & 76,5069 & 12,73384 & & \multirow{2}{*}{,- 685} & \multirow{2}{*}{,494 } \\
\hline & & Bekâr & 54 & 77,7778 & 12,59480 & & & \\
\hline
\end{tabular}

Tablo 6 incelendiğinde sınıf öğretmenlerinin medeni durumlarının iş doyumunun alt boyutu olan içsel doyum puanları üzerine etkisini incelemek amacıyla yapılan ilişkisiz örneklemler için t testi sonucuna göre, evli öğretmenlerin içsel doyum puanları $(\overline{\mathrm{X}}=47,61)$ ile bekâr öğretmenlerin içsel doyum puanları $(\overline{\mathrm{X}}=48,66)$ arasında istatistiksel olarak anlamlı bir farkın oluşmadığ 1 görülmüştür $\left(\mathrm{t}_{(2-415)}=-\right.$ ,940; $\mathrm{p}>0,05)$. Bu sonuçlara göre medeni durumun sınıf öğretmenlerinin içsel doyum puanları üzerinde etkisi olmadığı söylenebilir.

Sınıf öğretmenlerinin medeni durumlarının iş doyumu alt boyutu olan dışsal doyum puanları sonucuna göre evli öğretmenlerin dışsal doyum puanları $(\overline{\mathrm{X}}=28,89)$ ile bekâr öğretmenlerin dışsal doyum puanları $(\overline{\mathrm{X}}=29,11)$ arasında istatistiksel olarak anlamlı bir fark oluşturmadığ 1 görülmüştür $\left(\mathrm{t}_{(2-}\right.$ $\left.{ }_{415)}=-242 ; \mathrm{p}>0,05\right)$. Bu sonuçlara göre medeni durumun sınıf öğretmenlerinin dışsal doyum puanları üzerinde etkisi olmadığı görülmüştür.

Sınıf öğretmenlerinin medeni durumlarının iş doyum toplam puanları sonucuna göre evli öğretmenlerin iş doyum toplam puanları $(\overline{\mathrm{X}}=76,50)$ ile bekâr öğretmenlerin iş doyum toplam puanları $(\overline{\mathrm{X}}=77,77)$ arasında istatistiksel olarak anlamlı bir fark oluşturmadığı görülmüştür $\left(\mathrm{t}_{(2-415)}=-, 685\right.$; $\mathrm{p}>0,05)$. Bu sonuçlara göre medeni durumun sınıf öğretmenlerinin iş doyum toplam puanları üzerinde etkisi olmadığ bulgusuna ulaşılmıştır.

Sınıf öğretmenlerinin iş doyumu düzeylerinin mesleki kıdeme göre farklılığı Kruskal-Wallis H Testi analizi Tablo 7'de sunulmaktadır.

Tablo 7 
Sinıf Öğretmenlerinin İs Doyumu Düzeylerinin Mesleki Kıdeme Göre Farklılı̆̆ı Kruskal-Wallis H Testi Analizi

\begin{tabular}{|c|c|c|c|c|c|c|c|}
\hline & & Kidem & $\mathrm{n}$ & Sira Ortalamas1 & sd & $\chi^{2}$ & $\mathrm{p}$ \\
\hline \multirow{18}{*}{ 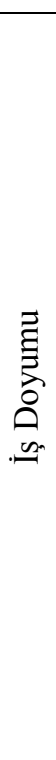 } & & $1-5$ y1l & 39 & 214,77 & \multirow{6}{*}{5} & \multirow{6}{*}{,685 } & \multirow{6}{*}{,98 } \\
\hline & & $6-10$ y1l & 70 & 199,09 & & & \\
\hline & İçsel & $11-15$ y1l & 69 & 206,25 & & & \\
\hline & \multirow[t]{3}{*}{ Doyum } & $16-20 \mathrm{y} 11$ & 56 & 214,21 & & & \\
\hline & & $21-25$ y1l & 62 & 209,04 & & & \\
\hline & & 26 yll ve üzeri & 119 & 208,58 & & & \\
\hline & \multirow{6}{*}{ Dişsal Doyum } & $1-5 \mathrm{y} 11$ & 39 & 188,88 & \multirow{6}{*}{5} & \multirow{6}{*}{3,186} & \multirow{6}{*}{,671 } \\
\hline & & $6-10 \mathrm{y} 1 \mathrm{l}$ & 70 & 198,96 & & & \\
\hline & & $11-15$ y1l & 69 & 208,24 & & & \\
\hline & & $16-20$ yil & 56 & 225,85 & & & \\
\hline & & $21-25$ y1l & 62 & 201,31 & & & \\
\hline & & 26 yll ve üzeri & 119 & 214,53 & & & \\
\hline & \multirow{6}{*}{$\begin{array}{l}\text { İş Doyum } \\
\text { Toplam }\end{array}$} & $1-5 \mathrm{y} 11$ & 39 & 202,83 & \multirow{6}{*}{5} & \multirow{6}{*}{1,787} & \multirow{6}{*}{, 878} \\
\hline & & $6-10$ yil & 70 & 196,82 & & & \\
\hline & & $11-15$ y1l & 69 & 205,28 & & & \\
\hline & & $16-20 \mathrm{y} 11$ & 56 & 221,20 & & & \\
\hline & & $21-25$ y1l & 62 & 203,42 & & & \\
\hline & & 26 yll ve üzeri & 119 & 214,03 & & & \\
\hline
\end{tabular}

Tablo 7 incelediğinde sınıf öğretmenlerinin iş doyum alt boyutu olan içsel doyum puanlarının mesleki kıdemlerine göre anlamlı olarak farklılaşıp farklılaşmadığını belirlemek için yapılan KruskalWallis $\mathrm{H}$ testi sonucunda, içsel doyum ile mesleki kıdem arasında istatistiksel olarak anlamlı fark olmadığı görülmüştür $\left[\chi^{2}{ }_{(5)}=, 685 ; p>0.05\right]$. Bu sonuçlara göre mesleki kıdemin sınıf öğretmenlerinin içsel doyum puanları üzerinde etkisi olmadığı söylenebilir.

Sınıf öğretmenlerinin mesleki kıdemlerinin iş doyumu alt boyutu olan dışsal doyum puanlarına bakıldığında, dışsal doyum ile mesleki kıdem arasında istatistiksel olarak anlamlı fark olmadığı görülmüştür $\left[\chi^{2}{ }_{(5)}=3,186 ; \mathrm{p}>0\right.$. 05]. Bu sonuçlara göre mesleki kıdemin sınıf öğretmenlerinin $d \iota s ̧ s a l$ doyum puanları üzerinde etkisi olmadığı görülmüştür.

Sınıf öğretmenlerinin mesleki kıdemlerinin iş doyum toplam puanlarına bakıldığında, iş doyumu ile mesleki kıdem arasında istatistiksel olarak anlamlı fark olmadığı görülmüştür $\left[\chi_{(5)}^{2}=1,787 ; p>0,05\right]$. $\mathrm{Bu}$ sonuçlara göre mesleki kıdemin sınıf öğretmenlerinin toplam iş doyum puanları üzerinde etkisi olmadığı bulgusuna ulaşılmıştır.

\section{Sınıf Öğretmenlerinin İş Yaşamında Yalnızlık Düzeyleriyle İlgili Bulgular}

Sınıf öğretmenlerinin iş yaşamında yalnızlık düzeyleri Tablo 8'de sunulmuştur.

Tablo 8

Sınıf Öğretmenlerinin Iş̧ Yaşamında Yalnızlık Düzeyleri

\begin{tabular}{|c|c|c|c|c|c|c|c|c|c|}
\hline & Alt Boyutla & & Düşük & Orta & Yüksek & Min. & Mak. & $\overline{\mathrm{X}}$ & $\mathrm{S}$ \\
\hline \multirow{7}{*}{ 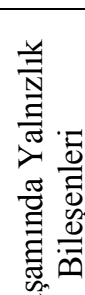 } & \multirow{3}{*}{$\begin{array}{l}\text { Duygusal } \\
\text { Yoksunluk }\end{array}$} & Aralık & $9-17$ & $18-27$ & $28-36$ & \multirow{3}{*}{9} & \multirow{3}{*}{45} & \multirow{3}{*}{16,8916} & \multirow{3}{*}{6,54825} \\
\hline & & f & 242 & 140 & 33 & & & & \\
\hline & & $\%$ & 58,3 & 33,7 & 8 & & & & \\
\hline & \multirow{3}{*}{$\begin{array}{l}\text { Sosyal } \\
\text { Arkadaşlık }\end{array}$} & Aralık & $7-16$ & $17-25$ & $26-35$ & \multirow{3}{*}{7} & \multirow{3}{*}{34} & \multirow{3}{*}{13,3880} & \multirow{3}{*}{5,33889} \\
\hline & & $\mathrm{f}$ & 328 & 74 & 13 & & & & \\
\hline & & $\%$ & 79,1 & 17,8 & 3,1 & & & & \\
\hline & \multirow{3}{*}{$\begin{array}{l}\text { İş } \\
\text { Yaşamında } \\
\text { Yalnızlık }\end{array}$} & Aralık & $16-37$ & $38-58$ & $59-80$ & \multirow{3}{*}{16} & \multirow{3}{*}{76} & \multirow{3}{*}{30,2795} & \multirow{3}{*}{10,95043} \\
\hline$\lambda$ & & $\mathrm{f}$ & 328 & 81 & 6 & & & & \\
\hline & & $\%$ & 79,1 & 19,5 & 1,4 & & & & \\
\hline
\end{tabular}


Tablo 8'de görüldüğü gibi sınıf öğretmenlerinin duygusal yoksunluk alt boyutu puanları 9 ile 45 arasında değişmektedir. Duygusal yoksunluk düzeylerine ilişkin veriler incelendiğinde sınıf öğretmenlerinin \%58,3'ü düşük düzey duygusal yoksunluk, \%33,7'si orta düzey duygusal yoksunluk, \%8'i yüksek düzey duygusal yoksunluğa sahip oldukları görülmektedir. Sınıf öğretmenlerinin duygusal yoksunluk ortalamasına bakıldığında ise $\overline{\mathrm{X}}=16,89$ ile düşük düzey duygusal yoksunluğa sahip oldukları söylenebilir.

Sınıf öğretmenlerinin sosyal arkadaşlık alt boyutu puanları 7 ile 34 arasında değişmektedir. Sosyal arkadaşlık düzeylerine ilişkin veriler incelendiğinde sınıf öğretmenlerinin \% $\%$, 1 'i düşük düzey, \%17,8’i orta düzey \%3,1'i yüksek düzey sosyal arkadaşlığa sahip oldukları görülmektedir. Sınıf öğretmenlerinin sosyal arkadaşlık ortalamasına bakıldığında ise $\overline{\mathrm{X}}=13,38$ ile düşük düzey sosyal arkadaşlı̆̆a sahip oldukları söylenebilir.

Sınıf öğretmenlerinin iş yaşamında yalnızlık toplam puanları 16 ile 76 arasında değişmektedir. Işs yaşamında yalnızlık düzeylerine ilişkin veriler incelendiğinde sınıf öğretmenlerinin \%79,1'i düşük düzey, \%19,5’i orta düzey ve \%1,4'ünün ise yüksek düzey iş yaşamında yalnızlı̆g sahip oldukları görülmektedir. Sınıf öğretmenlerinin iş yaşamında yalnızlık ortalamasına bakıldığında ise $\bar{X}=30,27$ ile düşük düzey iş yaşamında yalnızlı̆̆a sahip oldukları söylenebilir.

Sınıf öğretmenlerinin iş yaşamında yalnızlık puanlarının cinsiyete göre farklılığı Mann-Whitney U Testi analizi Tablo 9'da verilmiştir.

Tablo 9

Sınıf Öğretmenlerinin İş Yaşamında Yalnızlık Puanlarının Cinsiyete Göre Farklıllğ̆ Mann-Whitney U Testi Analizi

\begin{tabular}{|c|c|c|c|c|c|c|c|}
\hline & & Cinsiyet & $\mathrm{n}$ & $\begin{array}{c}\text { Sira } \\
\text { Ortalamas1 }\end{array}$ & $\begin{array}{c}\text { Sira } \\
\text { Toplamı }\end{array}$ & $\mathrm{U}$ & $\mathrm{p}$ \\
\hline \multirow{6}{*}{ 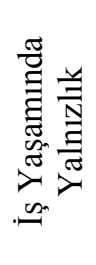 } & \multirow{2}{*}{$\begin{array}{l}\text { Duygusal } \\
\text { Yoksunluk }\end{array}$} & Kadın & 190 & 204,56 & 38865,50 & \multirow{2}{*}{20720,50} & \multirow{2}{*}{, 590} \\
\hline & & Erkek & 225 & 210,91 & 47454,50 & & \\
\hline & \multirow{2}{*}{$\begin{array}{l}\text { Sosyal } \\
\text { Arkadaşlık }\end{array}$} & Kadın & 190 & 195,31 & 37109,50 & \multirow[t]{2}{*}{18964,50} & \multirow[t]{2}{*}{, $047 *$} \\
\hline & & Erkek & 225 & 218,71 & 49210,50 & & \\
\hline & \multirow{2}{*}{ Toplam } & Kadın & 190 & 199,92 & 37984,00 & \multirow{2}{*}{19839,00} & \multirow{2}{*}{,207 } \\
\hline & & Erkek & 225 & 214,83 & 48336,00 & & \\
\hline
\end{tabular}

Tablo 9'da sınıf öğretmenlerinin iş yaşamında yalnızlık puanlarının cinsiyete göre anlamlı bir farkın olup olmadığı Mann-Whitney U Testi ile hesaplanmıştır. Hesaplanan Mann-Whitney U değeri ve \%95 güven aralığında anlamlılık düzeyine göre $(U=20720,50 ; p>0,05)$ kadın öğretmenler ile erkek öğretmenlerin duygusal yoksunluk puanları arasında istatistikî olarak anlamlı fark olmadığ görülmüştür. Bu sonuçlara göre cinsiyetin sınıf öğretmenlerinin duygusal yoksunluk puanları üzerinde etkisi olmadığı söylenebilir.

Sınıf öğretmenlerinin cinsiyetlerinin iş yaşamında yalnızlık alt boyutu olan sosyal arkadaşlık puanlarına göre $(U=18964,50 ; p<0,05)$ kadın ve erkek öğretmenler arasında istatistikî olarak anlamlı fark olduğu görülmüş̧ür. Erkek öğretmenlerin sosyal arkadaşlı puanlarının kadın öğretmenlerin sosyal arkadaşlık puanlarından daha yüksek olduğu belirlenmiştir. Bu sonuçlara göre erkek ögretmenlerin kadın öğretmenlere göre sosyal arkadaşlık alt boyutunda daha yalnız hissettikleri söylenebilir.

Sınıf öğretmenlerinin cinsiyetlerinin iş yaşamında yalnızlık toplam puanlarına göre (U= $19839,00 ; \mathrm{p}>0,05)$ kadın ile erkek öğretmenler arasında istatistikî olarak anlamlı fark olmadığı görülmüştür. Bu sonuçlara göre cinsiyetin sınıf öğretmenlerinin iş yaşamında yalnızlık toplam puanları üzerinde etkisi olmadığ 1 söylenebilir. 
Sınıf öğretmenlerinin iş yaşamında yalnızlık puanlarının medeni duruma göre farklılığı $t$ Testi analizi Tablo 10'da sunulmuştur.

Tablo 10

Sınıf Öğretmenlerinin İş Yaşamında Yalnızlık Puanlarının Medeni Duruma Göre Farklılığı t Testi Analizi

\begin{tabular}{|c|c|c|c|c|c|c|c|c|}
\hline & & $\begin{array}{l}\text { M. } \\
\text { Durum }\end{array}$ & $\mathrm{n}$ & $\overline{\mathrm{X}}$ & SS & $\mathrm{Sd}$ & $\mathrm{t}$ & $\mathrm{p}$ \\
\hline \multirow{6}{*}{ 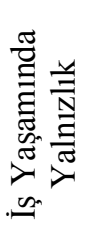 } & Duygusal & Evli & 361 & 16,79 & 6,55 & \multirow{2}{*}{413} & \multirow{2}{*}{,- 799} & \multirow{2}{*}{,425 } \\
\hline & Yoksunluk & Bekâr & 54 & 17,55 & 6,49 & & & \\
\hline & Sosyal & Evli & 361 & 13,25 & 5,19 & \multirow{2}{*}{413} & \multirow{2}{*}{$-1,314$} & \multirow{2}{*}{ 189 } \\
\hline & Arkadaşl1k & Bekâr & 54 & 14,27 & 6,18 & & & \\
\hline & \multirow{2}{*}{ Toplam } & Evli & 361 & 30,04 & 10,87 & \multirow{2}{*}{413} & \multirow{2}{*}{$-1,118$} & \multirow{2}{*}{,264 } \\
\hline & & Bekâr & 54 & 31,83 & 11,42 & & & \\
\hline
\end{tabular}

Tablo 10 incelendiğinde sınıf öğretmenlerinin medeni durumlarının iş yaşamında yalnızlık alt boyutu olan duygusal yoksunluk puanlarına üzerine etkisini incelemek amacıyla yapılan ilişkisiz örneklemler için t testi sonucuna göre evli öğretmenlerin duygusal yoksunluk puanları $(\overline{\mathrm{X}}=16,79)$ ile bekâr öğretmenlerin duygusal yoksunluk puanları $(\overline{\mathrm{X}}=17,55)$ arasında istatistiksel olarak anlamlı bir fark oluşturmadığı görülmüştür $\left(\mathrm{t}_{(2-413)}=-, 799 ; \mathrm{p}>0,05\right)$. Bu sonuçlara göre medeni durumun sınıf öğretmenlerinin duygusal yoksunluk puanları üzerinde etkisi olmadığı söylenebilir.

Sınıf öğretmenlerinin medeni durumlarının iş yaşamında yalnızlık alt boyutu olan sosyal arkadaşlık puanları sonucuna göre evli öğretmenlerin sosyal arkadaşlık puanları $(\overline{\mathrm{X}}=13,25)$ ile bekâr ögretmenlerin sosyal arkadaşlık puanları $(\overline{\mathrm{X}}=14,27)$ arasında istatistiksel olarak anlamlı bir fark oluşturmadığ görülmüştür ( $\left.{ }_{(2-413)}=-1,314 ; p>0,05\right)$. Bu sonuçlara göre medeni durumun sınıf öğretmenlerinin sosyal arkadaşlık puanları üzerinde etkisi olmadığı söylenebilir.

Sınıf öğretmenlerinin medeni durumlarının iş yaşamında yalnızlık toplam puanları sonucuna göre evli öğretmenlerin iş yaşamında yalnızlık toplam puanları $(\overline{\mathrm{X}}=30,04)$ ile bekâr öğretmenlerin $i$ ş yaşamında yalnızlık toplam puanları $(\overline{\mathrm{X}}=31,83)$ arasında istatistiksel olarak anlamlı bir fark oluşturmadığ 1 görülmüştür ( $\left.\mathrm{t}{ }_{(2-413)}=-1,118 ; \mathrm{p}>0.05\right)$. Bu sonuçlara göre medeni durumun sınıf öğretmenlerinin iş yaşamında yalnızlık toplam puanları üzerinde etkisi olmadığı söylenebilir.

Sınıf öğretmenlerinin iş yaşamında yalnızlık puanlarının mesleki kıdeme göre farklılığı Kruskal-Wallis H Testi analizi Tablo 11'de sunulmuştur

Tablo 11

Sınıf Öğretmenlerinin Işs Yaşamında Yalnızlık Puanlarının Mesleki Kıdeme Göre Farklılı̆̆ KruskalWallis H Testi Analizi

\begin{tabular}{|c|c|c|c|c|c|c|c|c|}
\hline & & Kidem & $\mathrm{n}$ & Sira Ortalamas & sd & $x^{2}$ & $\mathrm{p}$ & $\begin{array}{c}\text { Anlamlı } \\
\text { Farkın } \\
\text { Kaynağ } 1\end{array}$ \\
\hline \multirow{9}{*}{ 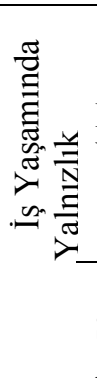 } & \multirow{6}{*}{$\begin{array}{l}\text { Duygusal } \\
\text { Yoksunluk }\end{array}$} & $1-5$ y1l (1) & 39 & 270,31 & \multirow{6}{*}{5} & \multirow{6}{*}{18,27} & \multirow{6}{*}{, $003 *$} & $1-2$ \\
\hline & & $6-10$ y1l (2) & 70 & 206,56 & & & & $1-3$ \\
\hline & & $11-15$ y1l (3) & 69 & 202,96 & & & & $1-4$ \\
\hline & & $16-20$ yil (4) & 56 & 207,14 & & & & $1-5$ \\
\hline & & $21-25$ yil (5) & 62 & 166,84 & & & & $1-6$ \\
\hline & & 26 yıl ve üzeri (6) & 119 & 213,20 & & & & $5-6$ \\
\hline & \multirow{3}{*}{$\begin{array}{l}\text { Sosyal } \\
\text { Arkadaşlık }\end{array}$} & $1-5$ y1l (1) & 39 & 258,13 & \multirow{3}{*}{5} & \multirow{3}{*}{12,31} & \multirow{3}{*}{, $031^{*}$} & $1-2$ \\
\hline & & $6-10$ y1l (2) & 70 & 202,11 & & & & $1-4$ \\
\hline & & $11-15$ yil (3) & 69 & 216,84 & & & & $1-5$ \\
\hline
\end{tabular}




\begin{tabular}{|c|c|c|c|c|c|c|c|}
\hline & $16-20$ y1l (4) & 56 & 199,77 & & & & $1-6$ \\
\hline & $21-25$ y1l (5) & 62 & 175,63 & & & & $5-6$ \\
\hline & 26 yıl ve üzeri (6) & 119 & 210,65 & & & & \\
\hline \multirow{6}{*}{ Toplam } & $1-5$ yil (1) & 39 & 267,58 & \multirow{6}{*}{5} & \multirow{6}{*}{17,16} & \multirow{6}{*}{, $004^{*}$} & $1-2$ \\
\hline & $6-10$ yil (2) & 70 & 206,31 & & & & $1-3$ \\
\hline & $11-15$ y1l (3) & 69 & 207,32 & & & & $1-4$ \\
\hline & $16-20$ y1l (4) & 56 & 203,53 & & & & $1-5$ \\
\hline & $21-25$ y1l (5) & 62 & 167,15 & & & & $1-6$ \\
\hline & 26 yıl ve üzeri (6) & 119 & 213,25 & & & & $5-6$ \\
\hline
\end{tabular}

Tablo 11'de sınıf öğretmenlerinin iş yaşamında yalnızlık puanlarının mesleki kıdemlerine göre istatistikî olarak anlamlı bir farkın olup olmadığ Kruskal-Wallis H Testi ile hesaplanmıştır. Tablo 4.2.3. incelendiğinde sınıf öğretmenlerinin duygusal yoksunluk alt boyutu ile mesleki kıdemleri arasında istatistikî olarak anlamlı farklılığın olduğu tespit edilmiştir $\left[\chi_{(5)}^{2}=18,27 ; p<0,05\right]$. MannWhitney U testi ile yapılan çoklu karşılaştırmalar sonunda bu farkın 1-2., 1-3., 1-4., 1-5., 1-6. ve 5-6. gruplar arasında olduğu belirlenmiştir. Bu sonuçlara göre 1-5 yıl arasında mesleki kıdeme sahip sınıf ögretmenlerinin duygusal yoksunluk puanlarının 6-10 yıl, 11-15 yıl, 16-20 yıl, 21-25 yıl ve 26 yıl ve üzeri mesleki kıdeme sahip öğretmenlerin duygusal yoksunluk puanlarından daha yüksek olduğu görülmektedir. Ayrıca 26 yıl ve üzeri mesleki kıdeme sahip öğretmenlerin 21-25 yıl mesleki kıdeme sahip öğretmenlerden duygusal yoksunluk puanlarından daha yüksek olduğu görülmektedir. 1-5 yıl mesleki kıdeme sahip sınıf öğretmenlerinin diğer mesleki kıdemlere sahip sınıf öğretmenlerinden; 26 yıl ve üzeri mesleki kıdeme sahip sınıf öğretmenlerinin 21-25 yıl mesleki kıdeme ise sahip sınıf öğretmenlerinden duygusal yoksunluk boyutunda daha yalnız oldukları söylenebilir.

Sınıf öğretmenlerinin mesleki kıdemlerinin iş yaşamında yalnızlık alt boyutu olan sosyal arkadaşlık puanlarına bakıldığında aralarında istatistikî olarak anlamlı farkın olduğu görülmüştür $\left[\chi_{(5)}^{2}\right.$ $=12,31 ; \mathrm{p}<0,05]$. Mann-Whitney U testi ile yapılan çoklu karşılaştırmalar sonunda bu farkın 1-2., 14., 1-5., 1-6. ve 5-6. gruplar arasında olduğu belirlenmiştir. Bu sonuçlara göre 1-5 yıl arasında mesleki kıdeme sahip sınıf öğretmenlerinin sosyal arkadaşlık puanlarının 6-10 yıl, 11-15 yı1, 16-20 yıl, 21-25 yıl ve 26 yıl ve üzeri mesleki kıdeme sahip sinıf öğretmenlerinden; 26 yıl ve üzeri mesleki kıdeme sahip sınıf öğretmenlerinin ise 21-25 yıl mesleki kıdeme sahip sınıf öğretmenlerinden sosyal arkadaşlık puanlarından daha yüksek olduğu görülmektedir. 1-5 yıl mesleki kıdeme sahip sınıf öğretmenlerinin 11-15 yıl mesleki kıdeme sahip sınıf öğretmenleri hariç diğer mesleki kıdemlere sahip sınıf öğretmenlerinden; 26 yıl ve üzeri mesleki kıdeme sahip sınıf öğretmenlerinin ise 21-25 yıl mesleki kıdeme sahip sınıf öğretmenlerinden sosyal arkadaşlık boyutunda daha yalnız oldukları söylenebilir.

Sınıf öğretmenlerinin mesleki kıdemlerinin iş yaşamında yalnızlık toplam puanlarına bakıldığında aralarında anlamlı bir farkın olduğu görülmüştür. $\left[\chi_{(5)}^{2}=17,16 ; p<0,05\right]$. Mann-Whitney U testi ile yapılan çoklu karşılaştırmalar sonunda bu farkın 1-2., 1-3., 1-4., 1-5., 1-6. ve 5-6. gruplar arasında olduğu belirlenmiştir. Bu sonuçlara göre 1-5 yıl arasında mesleki kıdeme sahip sınıf öğretmenlerinin iş yaşamında yalnızlık toplam puanlarının 6-10 y1l, 11-15 y1l, 16-20 y1l, 21-25 yıl ve 26 yıl ve üzeri mesleki k1deme sahip öğretmenlerden; 26 yıl ve üzeri öğretmenlerin ise 21-25 y1l mesleki kıdeme sahip öğretmenlerden iş yaşamında yalnızlık toplam puanlarından daha yüksek olduğu görülmektedir. 1-5 yıl mesleki kıdeme sahip sınıf öğretmenlerinin diğer mesleki kıdemlere sahip öğretmenlerden; 26 yıl ve üzeri mesleki kıdeme sahip sınıf öğretmenlerinin ise 21-25 yıl mesleki kıdeme sahip sınıf öğretmenlerinden iş yaşamında daha yalnız oldukları söylenebilir.

\section{Sınıf Öğretmenlerinin İş Doyumu ve İş Yaşamında Yalnızlık Arasındaki İlişki}

Sınıf öğretmenlerinin iş doyumu ölçeğinden alınan puanlarla iş yaşamında yalnızlık ölçeğinden alınan puanlar arasındaki ilişkiyi belirlemek üzere yapılan analize ilişkin bulgular Tablo 12'de verilmiştir. 
Tablo 12

Sinıf Öğretmenlerinin İs Doyumu ve İş Yaşamında Yalnızlık Ölçeğinden Aldıkları Puanlar Arasındaki İlişkiyi Belirlemek Üzere Yapılan Pearson Korelasyon Analizi Bulguları

\begin{tabular}{lccc}
\hline Değişkenler & $\mathrm{n}$ & $\mathrm{r}$ & $\mathrm{p}$ \\
\hline İş Doyumu & 415 &,- 402 & 0,000 \\
İş Yaşamında Yalnızlık & & & \\
\hline
\end{tabular}

Tablo 12'den de anlaşılacağı üzere, sınıf öğretmenlerinin iş doyumu ölçeğinden alınan puanlarla iş yaşamında yalnızlık ölçeğinden aldıkları puanlar arasındaki ilişkiyi belirlemek üzere yapılan Pearson Korelasyon analizi sonucunda puanlar arasında, negatif yönde güçlü ve istatistiksel açıdan anlamlı düzeyde bir ilişki olduğu saptanmıştır $(\mathrm{r}=-0,402, \mathrm{p}<0,05)$. Bu sonuca göre sınıf öğretmenlerinin iş doyumu artarken iş yaşamında yalnızlıklarının azaldığı, iş doyumu azalırken iş yaşamında yalnızlıklarının da arttı̆̆ı söylenebilir.

\section{Sonuç, Tartışma ve Öneriler}

Sınıf öğretmenlerinin iş doyum ve iş yaşamında yalnızlık düzeylerini belirlemek amacıyla yapılan bu çalışmada, öğretmenler cinsiyet, medeni durum ve mesleki kıdem değişkenleri bakımından değerlendirilmiştir.

\section{Sınıf Öğretmenlerinin İş Doyum Düzeyi ile İlgili Sonuç ve Tartışma}

Çalışmanın bulgularına göre; sınıf öğretmenlerinin yüksek düzey içsel doyuma sahip oldukları sonucuna ulaşılmıştır. Bu sonuç literatürdeki bazı çalışmaların sonuçlarıyla örtüşmektedir (Çifçi ve Dikmenli, 2015; İdi, 2017; Özkan, 2017). Ayrıca literatürde bazı çalışmalarda öğretmenlerin orta düzey (Karakuzu, 2013); bazı çalışmalarda ise düşük düzey (Ingersoll, 2001; Skaalvik ve Skaalvik, 2011) iş doyumuna sahip oldukları tespit edilmiştir. Günümüzde her ne kadar değerini yitirmiş gibi görünse bile öğretmenlik, kültürümüzde önemli ve saygın bir meslektir. Sınıf öğretmenleri yetiştirdikleri başarılı öğrenciler nedeniyle okulun bulunduğu çevrede tanınmakta, sevilmekte ve saygı görmektedir. Öğrencilerin saflığı ve öğretmenlerine besledikleri karşılıksız sevgileri ise paha biçilemez değerdedir. Bu gibi durumların sınıf öğretmenlerinin içsel doyumlarını olumlu etkilediği düşünülmektedir.

Çalı̧̧manın bulgularına göre; sınıf öğretmenlerinin orta düzey dışsal doyuma sahip oldukları tespit edilmiştir. $\mathrm{Bu}$ sonuç literatürdeki bazı çalışmaların sonuçlarıyla örtüşmektedir (Çifçi ve Dikmenli, 2015; Karakuzu, 2013; Özkan, 2017). Ayrıca literatürde bazı çalışmalarda öğretmenlerin yüksek düzey dışsal doyuma sahip oldukları tespit edilmiş̧tir (İdi, 2017). Okullarda öğretmenlerin yöneticilerle yaşadıkları çeşitli problemler, okulun fiziki imkânlarının yetersizliği, öğretmenlik mesleğinden elde edilen ücretin yetersizliği gibi nedenlerin sınıf öğretmenlerinin dişsal doyum düzeylerini olumsuz etkilediği bu nedenle orta düzey dışsal doyum yaşadıkları düşünülmektedir.

Çalışmanın bulgularına göre; sınıf öğretmenlerinin yüksek düzey iş doyumuna sahip oldukları belirlenmiştir. Bu sonuç literatürdeki bazı çalışmaların sonuçlarıyla örtüşmektedir (Bakır ve Aslan, 2017; Başaran, 2017; İdi, 2017; Özarı ve Alızada, 2017). Ayrıca literatürde bazı çalışmalarda öğretmenlerin orta düzey veya kısmen doyumlu düzey iş doyum düzeylerine sahip oldukları tespit edilmiştir (Çanak, 2014; Erdoğan, 2017; Karakuzu, 2013; Ünal, 2015). Diğer meslek gruplarından farklı olarak öğretmenlerin iş doyumlarını yaptıkları işin karşılığında aldıkları manevi hazzın olumlu yönde etkilediği düşünülmektedir. Ayrıca öğretmenlerin yetiştirdiği öğrencilerini ileriki yıllarda farklı mevki ve statüde görmeleri, aynı saygıyı öğrencilerinin göstermeleri ve sahip çıkmaları öğretmenlerin iş doyum düzeylerinin artmasında etkili olduğu söylenebilir. 
Cinsiyet değişkeni ile sınıf öğretmenlerinin içsel doyum, dışsal doyum ve iş doyum puanları arasında istatistiksel olarak anlamlı bir fark oluşmadığı sonucuna ulaşılmıştır. Bu sonuç literatürdeki bazı çalışmaların sonuçlarıyla örtüşmektedir (Başaran, 2017; Bil, 2018; Çifçi ve Dikmenli, 2015). Kadın ve erkeğin iş hayatında eşit şekilde yer almaya başlamaları, kadınların iş ve aile hayatında eskiye nazaran daha fazla söz sahibi olmaları, kadınların iş hayatında daha fazla sorumluluk almak istemeleri, öğretmenlik mesleğinin kadın ve erkeğe eşit iş yükü yüklemesi gibi nedenlerden dolayı cinsiyetin iş doyumu ve alt boyutlarında belirleyici olmaktan çıktığı düşünülmektedir. Fakat bazı çalışmalar da kadın öğretmenlerin iş doyum düzeylerinin daha yüksek (Çanak, 2014; Yılmaz, 2014; Koustelios, 2001; Sharma ve Joyti, 2009); bazı çalışmalarda ise erkek öğretmenlerin iş doyum düzeylerinin daha yüksek (Özkan, 2017) olduğu belirlenmiştir. Toplumsal rolleri ve okul dişında ev işleri ile daha fazla ilgilenmeleri kadın öğretmenlerin, iş doyum düzeylerini olumsuz yönde etkileyebilir. Ayrıca bazı çalışmalarda kadınların ve erkeklerin iş doyum düzeylerinin farklı çıkması çalışmanın yapıldığı yıla, bireyin yetiştiği ve çalıştığı bölgeye ve sosyo kültürel çevreye bağlanabilir.

Medeni durum ile sınıf öğretmenlerinin içsel doyum, dışsal doyum ve iş doyum puanları arasında istatistiksel olarak anlamlı bir fark oluşmadığı sonuçlarına ulaşılmıştır. Bu sonuçlar literatürdeki bazı çalışmaların sonuçlarıyla örtüşmektedir (Bil, 2018; Erdoğan, 2017; Ünal, 2015). Ayrıca bazı çalışmalarda evli öğretmenlerin iş doyum düzeylerinin daha yüksek (Çanak, 2014; Gündoğdu, 2013; Sharma ve Jyoti, 2009); bazı çalışmalarda ise bekâr öğretmenlerin iş doyum düzeylerinin daha yüksek (Yavuzkurt, 2017) olduğu tespit edilmiştir. Sınıf öğretmenlerinin iş doyum düzeylerini, medeni durumlarından daha çok, bireylerin öğretmenlik mesleğini isteyerek seçmeleri, öğrencilerini aile ferdi olarak görmeleri ve öğrencilerin başarılı olmaları için var güçleri ile çalışmaları etkilediği düşünülmektedir.

Mesleki kıdem ile sınıf öğretmenlerinin içsel doyum, dışsal doyum ve iş doyum puanları arasında istatistiksel olarak anlamlı bir fark oluşmadığı sonucuna ulaşılmıştır. Bu sonuçlar literatürdeki bazı çalışmaların sonuçlarıyla örtüşmektedir (Çanak, 2014; Erdoğan, 2017; Karakuzu, 2013; Sharma ve Jyoti, 2009). Ayrıca bazı çalışmalarda ise farklı sonuçlara ulaşıldığı tespit edilmiştir (Gündoğdu, 2013; Yavuzkurt, 2017; Yılmaz, 2014; Bil, 2018). İş doyum düzeyini mesleki kıdemden ziyade diğer değişkenlerin daha fazla etkilediği düşünüldüğü için çalışma yılının iş doyumuna önemli bir yansımasının olmadığı söylenebilir.

\section{Sınıf Öğretmenlerinin İş Yaşamında Yalnızlık Düzeyleri ile İlgili Sonuç ve Tartışma}

Çalışmanın bulgularına göre sınıf öğretmenlerinin düşük düzey duygusal yoksunluk, sosyal arkadaşlık ve iş yaşamında yalnızlığa sahip oldukları sonuçlarına ulaşılmıştır. $\mathrm{Bu}$ sonuçlar literatürdeki bazı çalışmaların sonuçlarıyla örtüşmektedir (Demirbaş ve Haşit, 2016; Oğuz ve Kalkan, 2014;). Bazı çalışmalarda ise farklı sonuçlara ulaşıldığı görülmektedir (Bakır ve Aslan, 2017; Çifçi ve Dikmenli, 2015; Tabak ve Argon, 2018). Genel olarak sınıf öğretmenlerinin branş öğretmenlerine göre hem öğrenci hem de velileri ile daha uzun ve daha güçlü iletişim ve etkileşimlerinin olması yalnızlık düzeylerinin düşük olmasını etkilediği düşünülmektedir.

Cinsiyet değişkenine göre sınıf öğretmenlerinin duygusal yoksunluk ve işs yaşamında yalnızlık puanları arasında istatistiksel olarak anlamlı bir fark oluşmadığı, ancak erkek öğretmenlerin sosyal arkadaşlık boyutunda kadın öğretmenlerden daha yalnız oldukları sonuçlarına ulaşılmıştır. Bazı çalışmalarda öğretmenlerin iş yaşamında yalnızlıklarının cinsiyete göre farklılaşmadığı belirlenirken (Karaduman, 2013; Mercan vd., 2012; Oğuz ve Kalkan, 2014; Kılıç, 2018); bazı çalışmalarda kadın öğretmenlerin (Demirbaş ve Haşit, 2016); bazı çalışmalarda ise erkek öğretmenlerin (Yukay Yüksel vd., 2013; Yakut ve Certel, 2016) daha yalnız hissettikleri tespit edilmiştir. Çeşitli nedenlerle toplumdaki cinsiyet ayrımının ortadan kalkması, kadınların çalışma hayatında daha çok yer almaya başlaması, öğretmenlik mesleğinin her iki cins içinde eşit iş yükü yüklemesi vb. nedenler sınıf öğretmenlerinin cinsiyetlerinin iş yaşamında yalnızlık ve duygusal yoksunluk düzeyleri üzerindeki etkiyi azalttı̆̆ 1 söylenebilir. Ayrıca kadın öğretmenlerin öğretmenler odasını daha aktif kullanmaları, daha çabuk arkadaşlık ilişkileri kurabilme becerilerine sahip olmaları, okul dışında çeşitli etkinliklere 
yer vermeleri gibi nedenler arkadaş sayılarını arttırırken sosyal arkadaşlık düzeylerini de olumlu şekilde etkilediği söylenebilir.

Medeni durum değişkenine göre sınıf öğretmenlerinin duygusal yoksunluk, sosyal arkadaşlık ve iş yaşamında yalnızlık puanları arasında istatistiksel olarak anlamlı bir fark oluşmadığı sonuçlarına ulaşılmıştır. Bu sonuçlar literatürdeki bazı çalışmaların sonuçlarıyla örtüşmektedir (Çifçi ve Dikmenli, 2015; Kılıç, 2018; Mercan vd., 2012; Yakut ve Certel, 2016; Yukay Yüksel vd., 2013). Ayrıca literatür incelendiğinde bazı çalışmalar da bekar öğretmenlerin daha yalnız olduğu belirlenmiştir (Bakioğlu ve Korumaz, 2014; Neto, 2015). Türk toplumunun güçlü aile bağlarına sahip olması, arkadaşlık, komşuluk ilişkilerinin gelişmiş olması ve sınıf öğretmenlerinin küçük yaş ögrencilerle ilgilenmeleri, onları kendi çocukları gibi görmeleri gibi nedenlerle medeni durumun sınıf öğretmenlerinin yalnızlık düzeylerini etkilemediği söylenebilir.

1-5 y1l mesleki kıdeme sahip sınıf öğretmenlerinin diğer mesleki kıdeme sahip öğretmenlerden, 26 yıl ve üzeri mesleki kıdeme sahip öğretmenlerin ise 21-25 y1l mesleki kıdeme sahip öğretmenlerden daha fazla duygusal yoksunluk yaşadıkları sonucuna ulaşılmıştır. Mesleki kıdemi 26 yıl ve üzeri olan sınıf öğretmenlerinin, mesleğe birlikte başladığı arkadaşlarının veya hayat arkadaşlarının (ölüm, emeklilik, tayin vb.) çeşitli nedenlerle hayatlarından çıkmaları, mesai arkadaşlarıyla yaşadıkları kuşak çatışmaları, teknolojideki yeniliklere ayak uyduramama ve emeklilik çağı gelmesine rağmen maddi sorunlar nedeniyle çalışmak zorunda olmaları gibi faktörlerden dolayı daha fazla duygusal yoksunluk yaşadıkları düşünülmektedir. 1-5 yıl mesleki kıdeme sahip sınıf öğretmenlerinin, 6-10 yıl, 16-20 yıl, 21-25 yıl ile 26 yıl ve üzeri mesleki kıdeme sahip sınıf öğretmenlerinden; 26 yıl ve üzeri mesleki kıdeme sahip sınıf öğretmenlerinin ise 21-25 yıl mesleki kıdeme sahip sınıf öğretmenlerinden sosyal arkadaşlık boyutunda daha yalnız oldukları sonuçlarına ulaşılmıştır. Öğretmenlik mesleğine yeni başlayan öğretmenlerin sosyal yaşamlarındaki arkadaşlıklarını geride bırakıp atandıkları yerde yeni arkadaş çevresi oluşturmakta zorlandıklarından dolayı sosyal arkadaşlık boyutunda daha fazla yalnızlık yaşadıkları düşünülmektedir. 1-5 yıl mesleki kıdeme sahip sınıf öğretmenlerinin diğer mesleki k1deme sahip sınıf öğretmenlerinden; 26 y1l ve üzeri mesleki kıdeme sahip sınıf öğretmenlerinin ise 21-25 yıl mesleki kıdeme sahip sınıf öğretmenlerinden iş yaşamında daha yalnız oldukları sonucuna ulaşılmıştır. 1-5 yıl mesleki kıdeme sahip olan öğretmenlerin mesleki tecrübelerinin düşük olması ve yeni bir sosyo kültürel çevreye adaptasyon sorunları yaşamları; 26 yıl ve üzeri mesleki kıdeme sahip sınıf öğretmenlerinin ise zaman içerisinde yer değiştirmeleri ve farklı sebeplerle arkadaş çevrelerinden uzaklaşmaları, kendilerini iş yaşamında daha yalnız hissetmelerine neden olduğu söylenebilir.

\section{İş Doyumu ve İş Yaşamında Yalnızlık Arasındaki İliş̧kiye Yönelik Sonuç ve Tartışma}

Sınıf öğretmenlerinin iş doyumu ve iş yaşamında yalnızlıkları arasında negatif yönde yüksek düzeyde ve istatistiksel açıdan anlamlı bir iliş̧ki olduğu sonucuna ulaşılmıştır. Bu sonuç literatürdeki bazı çalışmaların sonuçları ile örtüşürken (Çifçi ve Dikmenli, 2015; Neto, 2015; Tabancal1, 2016), bazı çalışmaların sonuçları ile örtüşmemektedir (Bakır ve Aslan, 2017; Chan ve Qiu, 2011). Genel olarak çalışanların iş doyum düzeyleri arttıkça iş yaşamında yalnızlık düzeylerinin azalma ihtimali beklenen bir sonuçtur. İş doyumuna ulaşan çalışanların daha mutlu ve umutlu olmaları nedeniyle umutsuzluğa ve yalnızlık hissine kapılmamalarının beklenen bir durum olduğu düşünülmektedir.

Sosyal arkadaşlık düzeyi düşük olan bireyin, iş yerindeki arkadaş sayısı az, sosyal ilişkileri zayıf, iş arkadaşlarıyla paylaşımları düşük ve arkadaşlarına olan güvenleri azalır (Karaduman, 2013; Wright, 2007). Sosyal arkadaşlık boyutunda yalnızlık hisseden bireylerde aykırılaşma, dışlanmışlık hissine kapılma, sıkılganlık ve kendilerini bir grubun üyesi olarak görmeme gibi durumlar ortaya çıkabilir (Mercan vd., 2012). Bu bağlamda sosyal arkadaşlık boyutunda okullarda yaşanabilecek olası bir yalnızlık durumu, öğretmenin mesai arkadaşlarıyla olan iletişimini olumsuz yönde etkileyerek okulun performansının ve başarısının düşmesine, öğretmenlerin ise iş doyum düzeylerinin azalmasına neden olabilir. Ayrıca çevresindeki kişilerin kendini anlamayacağını düşünen, ailesi ve mesai arkadaşlarıyla yetersiz ilişkileri olan ve iş yerinde kendini huzurlu hissetmeyen öğretmenlerin, duygusal yoksunluk yaşadıkları ifade edilmektedir (Mercan vd., 2012; Wright, 2007). Duygusal olarak 
kendini yoksun hisseden öğretmenlerin, diğer öğretmenler ile uyum ve güven içinde çalışmaları beklenemez. Öğretmenlerin sadece kişilik özellikleri ve sosyal zekâları değil aynı zamanda idarecilerin ve mesai arkadaşlarının birbirlerine karşı takındıkları tutum ve davranışlar ve okul içindeki iletişimin kalitesi de yalnızlık düzeyleri üzerinde önemli etkilere sahiptir. Çünkü okullarda öğretmenler arasında birlik, beraberlik, etkili iletişim, kurumsal bağl1lık ve destek arttıkça, okullarda yaşanan stres, güvensizlik, mutsuzluk, verimsizlik ve performans düşüklügü gibi olumsuz durumlar da azalacaktır. Bu durum ise öğretmenlerin iş yaşamlarında düşük yalnızlık yaşamalarında etkili olarak iş doyum düzeylerini arttıracaktır.

Bireyin öğretmenlik mesleğini yaparken hissettiği doyum, içsel doyumu; çalışması karşı1ığında elde ettiği doyum ise dişsal doyumu ifade etmektedir. Öğretmenlik mesleğinin bireyin ilgi ve yeteneklere uygun olması, yaratıcılığına imkân vermesi, çalışma ortamını sevmesi, iş arkadaşlarıyla etkili iletişim içinde olması, aldığı ücreti, maddi-manevi ödülleri yeterli bulması, okul yönetimi ve çalışma arkadaşlarının desteğini hissetmesi gibi faktörler öğretmenin iş doyum düzeyini olumlu yönde etkileyeceği düşünülmektedir. Tam tersi durumlarda ise öğretmenler kendilerini değersiz, ötekileşmiş ve yalnızlaşmış hissedebilirler. Bu nedenlerle kendini yalnız hisseden öğretmenin ise iş doyum düzeyi azalacaktır. İş doyum düzeyi azalan ve iş yaşamında yalnızlık düzeyi artan öğretmenlerin verimi ve performansı düşecektir. Bu durumda öğretmenlerin iş doyum düzeylerinin düşük olması ve iş yaşamlarındaki artan yalnızlıkları sadece kendilerini değil ailelerini, sosyal çevrelerini ve eğitim sisteminin en önemli çıktısı olan öğrenciler nezdinde geleceği ve bütün bir toplumu olumsuz etkileyebilecektir.

Okulların ve öğrencilerin başarıya ulaşabilmeleri için öğretmenlerin iş doyum düzeylerinin arttırılması ve iş yaşamındaki yalnızlık seviyelerinin ise en aza indirilmesi gerekmektedir. Sonuç olarak; öğretmenlerin iş doyum düzeyleri arttıkça iş yaşamındaki yalnızlıkları azalacak, iş yaşamındaki yalnızlıkları arttıkça iş doyum düzeyleri azalacaktır.

\section{Öneriler}

$\mathrm{Bu}$ araştırma nicel olarak kullanılmışolup, iş doyumunu ve iş yaşamında yalnızlığ 1 farklı boyutlarda derinlemesine incelemek için nitel araştırma yöntemleri veya karma yöntemler kullanılarak araştırılabilir.

Öğretmenlerin iş doyum düzeylerini arttırmak ve iş yaşamında yalnızlık düzeylerini azaltmak için özlük haklarıyla ilgili beklentilerin ve problemlerin çözülmesine yönelik çalışmalar yapılması önerilmektedir.

Öğretmenlerin iş doyumunu arttırmak ve iş yaşamındaki yalnızlık düzeylerini azaltmak için farklı şehirdeki öğretmenler seminer, toplantı vb. etkinlikler ile belirli aralıklarla bir araya getirilebilir.

Öğretmenlere yönelik adaletli taltif ve terfi sistemi geliştirilerek öğretmenlerin iş doyum düzeyleri arttırılabilir.

Öğretmenevleri, niceliksel ve niteliksel olarak daha uygun hale getirilebilir. Öğretmenlerin okul çıkışında kaliteli zaman geçirebilecekleri ve kendilerini geliştirebilecekleri mekânlara dönüştürülmesi sınıf öğretmenlerinin yalnızlık düzeylerini azaltabilir.

Öğretmenlerin iş doyumunu arttırmak ve iş yaşamındaki yalnızlık düzeylerini azaltmak için okullarda sosyal, kültürel ve sportif faaliyetlerin sayısı arttırılmalıdır.

Açılklamalar: Bu makalenin bir kısmı (ICOESS 2017) Uluslararası Sosyal Bilimler Kongresi'nde sözlü bildiri olarak sunulmuştur. Bu çalışma ikinci yazarın danışmanlığında birinci yazarın hazırladığı "Sınıf Öğretmenlerinin İş Doyumu ve İş Yaşamındaki Yalnızlık Düzeylerinin İncelenmesi" isimli Yüksek Lisans tezinden üretilmiştir. 


\section{Kaynaklar}

Akşit Aşık, D. (2010). Çalışanların iş doyumunu etkileyen bireysel ve örgütsel faktörler ile sonuçlarına ilişkin kavramsal bir değerlendirme. Türk İdare Dergisi, 467, 31-51.

Aktaş, A. M. (2001). Bir kamu kuruluşunun üst düzey yöneticilerinin iş stresi ve kişilik özellikleri. Ankara Üniversitesi SBF Dergisi, 56(4), 25-42.

Aydın, A., Sarıer, Y. ve Uysal, Ş. (2013). Okul müdürlerinin liderlik stillerinin, öğretmenlerin örgütsel bağlılığına ve iş doyumuna etkisi. Kuram ve Uygulamada Eğitim Bilimleri, 13(2), 795-811.

Bakır, A.A. and Aslan, M. (2017). Examınıng the relatıonshıp between princıpals' organızational lonelıness and job satisfaction levels. European Journal of Education Studies, 3(6), 50-71.

Bakioglu, A. ve Korumaz, M. (2014). Öğretmenlerin okulda yalnızlıklarının kariyer evrelerine göre incelenmesi. Eğitim Bilimleri Dergisi, 39, 25-54.

Balc1, A. (2011). Sosyal bilimlerde araştırma: Yöntem, teknik ve ilkeler. (9. Bas). Ankara: Pegem.

Başaran, M. (2017). Okul yöneticilerinin yönetim biçimleri ile öğretmenlerin iş doyumu arasındaki ilişkinin incelenmesi. Yüksek Lisans Tezi Gazi Üniversitesi Eğitim Bilimleri Enstitüsü, Ankara.

Baycan, A. (1985). An analysis of the several aspects of job satisfaction between differen to ccupational groups. Yayımlanmamış Doktora Tezi. Boğaziçi Üniversitesi Sosyal Bilimler Enstitüsü, İstanbul.

Bil, E. (2018). Ortaöğretim okullarının ögrenen örgüt, örgütsel güven ve iş doyumu düzeyleri arasındaki ilişki. Doktora Tezi. Ankara Üniversitesi Eğitim Bilimleri Enstitüsü, Ankara.

Bozkurt, Ö. ve Bozkurt, İ. (2008). İş tatminini etkileyen işletme içi faktörlerin eğitim sektörü açısından değerlendirilmesine yönelik bir alan araştırması. Doğuş Üniversitesi Dergisi, 9(1), $1-18$.

Chan, S. H. and Qiu, H. H. (2011). Loneliness, job satisfaction, and organizational commitment of migrant workers: Empirical evidence from China. The International Journal of Human Resource Management, 22(05), 1109-1127.

Çanak, M. (2014). Ortaöğretim kurumlarında görev yapan öğretmenlerin iş doyumlarının incelenmesi. OPUS Uluslararası Toplum Araştırmaları Dergisi, 4(7), 7-26.

Çetinkanat, C. (2000). Örgütlerde güdülenme ve iş doyumu. Ankara: Anı.

Çifçi, T. ve Dikmenli, Y. (2015). Coğrafya öğretmenlerinin iş doyumu ve iş yaşamında yalnızlık düzeylerinin incelenmesi. Akademik Sosyal Araştırmalar Dergisi, 3(21), 142-160.

Demir, M. (2011). İşgörenlerin çalışma yaşamı kalitesi algılamalarının işte kalma niyeti ve işe devamsızlık ile ilişkisi. Ege Akademik Bakış Dergisi, 11(3), 453-464.

Demirbaş, B. ve Haşit, G. (2016). İş yerinde yalnızlık ve işten ayrılma niyetine etkisi: akademisyenler üzerine bir uygulama. Anadolu Üniversitesi Sosyal Bilimler Dergisi, 16(1), 137-158.

Doğan, T., Çetin, B. ve Sungur, M. Z. (2009). İş Yaşamında Yalnızlık Ölçeği Türkçe formunun geçerlilik ve güvenilirlik çalışması. Anadolu Psikiyatri Dergisi, 10(6), 271-277.

Erdoğan, H. (2017). Ortaokul yöneticilerinin öğretim liderliği ile öğretmenlerin iş doyumu arasındaki ilişskinin incelenmesi. Yüksek Lisans Tezi. İstanbul Sabahattin Zaim Üniversitesi Sosyal Bilimler Enstitüsü, İstanbul.

Filiz, Z. (2014). Öğretmenlerin iş doyumu ve tükenmişlik düzeylerinin incelenmesi. Uluslararası Yönetim İktisat ve İsletme Dergisi, 10(23), 157-172.

Gündoğdu, G. B. (2013). Sinıf ögretmenlerinin iş doyumu ve mesleki tükenmişlik düzeyleri üzerine bir çalışma: Mersin ili örneği. Yüksek Lisans Tezi. Çağ Üniversitesi Sosyal Bilimler Enstitüsü, Mersin.

Ingersoll, R. M. (2001). Teacher turnover and teachers hortages: an organizational analysis. American Educational Research Journal, 38(3), 499-534. 
İdi, A. (2017). İlkokul ve ortaokullarda örgütsel iklim ile ögretmenlerin iş doyumu arasındaki ilişki. Yüksek Lisans Tezi. Dokuz Eylül Üniversitesi Eğitim Bilimleri Enstitüsü Eğitim Bilimleri Anabilim Dalı, İzmir.

İşcan, Ö. F. ve Sayın, U. (2010). Örgütsel adalet, iş tatmini ve örgütsel güven arasındaki ilişki. Atatürk Üniversitesi İktisadi ve İdari Bilimler Dergisi, 24(4), 195-216.

Kağan, M. (2010). Ankara ilindeki devlet ve özel ilköğretim okulları ile rehberlik ve araştırma merkezlerinde çalışan rehber öğretmenlerin iş doyumlarının incelenmesi. Erzincan Üniversitesi Ĕgitim Fakültesi Dergisi, 12(1). 39-55.

Karaduman, M. (2013). İş yaşamında yalnızlık algısının örgütsel vatandaşlık davranışı ile ilişkisi ve ögretmenler üzerinde bir uygulama. Yüksek Lisans Tezi. Uludağ Üniversitesi Sosyal Bilimler Enstitüsü, Bursa.

Karaköse, T. ve Kocabaş, İ. (2006). Özel ve devlet okullarında öğretmenlerin beklentilerinin iş doyumu ve motivasyon üzerine etkileri. Eğitimde Kuram ve Uygulama, 2(1), 3-14.

Karakuzu, S. (2013). Denizli il merkezinde bulunan ilkokullarda görev yapan sinı ögretmenleri ve ortaokullarda görev yapan branş ögretmenlerinin iş doyumunun incelenmesi. Yüksek Lisans Tezi. Gazi Üniversitesi Eğitim Bilimleri Enstitüsü, Ankara.

Karasar, N. (2005). Bilimsel araştırma yöntemi (17. Bask1). Ankara: Nobel.

Keser, A. ve Karaduman, M. (2014). İş yaşamında yalnızlık algısının örgütsel vatandaşlık davranışı ile ilişkisi ve öğretmenler üzerinde bir araştırma. Hak Işs Uluslararası Emek ve Toplum Dergisi, 3(7), 178- 197.

K1lıç, B. (2018). Issyyerinde yalnızlık ve işyerinde dışlanma sarmalında presenteeısm: bankacılık sektöründe bir araştırma. Yüksek Lisans Tezi. Selçuk Üniversitesi Sosyal Bilimler Enstitüsü, Konya

Koustelios, A. D. (2001). Personal characteristics and job satisfaction of Greek teachers. International Journal of Educational Management, 15(7), 354-358.

Mercan, N., Demirci, K., Özler, D. E., ve Oyur, E. (2015). İş yaşamında yalnızlık, duygusal zekâ ve psikolojik sermaye arasındaki ilişkiler üzerine bir araştırma. Manas Sosyal Araştırmalar Dergisi, 4(5). 197-211.

Mercan, N., Oyur, E., Alamur, B., Gül, S. ve Bengül, S. (2012). İşyeri yalnızlığı ve sosyal fobi arasındaki ilişkiye yönelik bir araştırma. Organizasyon ve Yönetim Bilimleri Dergisi, 4(1), 213-226.

Nartgün, Ş. S. ve Demirer, S. (2016). Öğretmenlerin örgütsel sessizlik ile iş yaşamında yalnızlık düzeylerine ilişkin görüşleri. Bayburt Eğitim Fakültesi Dergisi, 7(2), 139-156.

Neto, R. D. C. A. (2015). Teachers feel lonely too: a study of teachers' personal and professional characteristics associated with loneliness. Psico, 46(3), 321-330.

Oğuz, E. ve Kalkan, M. (2014). Öğretmenlerin iş yaşamında algıladıkları yalnızlık ile sosyal destek düzeyleri arasındaki ilişki. Illkögretim Online, 13(3), 787-785.

Özarı, Ç. ve Alızada, K. (2017). Akademik personelin tükenmişlik çısından değerlendirilmesi ve iş doyumuna yönelik bir araştırma. Ayrıntı Dergisi, 5(53), 58-65.

Özkalp, E. ve Kırel, Ç. (2001). Örgütsel davranış. Eskişehir: Anadolu Üniversitesi Eğitim Sağlık ve Bilimsel Araştırma Vakfi.

Özkan, A. (2017). Illkokul ve ortaokul ögretmenlerinin iş doyumu düzeyleri (Balıkesir ili merkez ilçeler örneği). Yüksek Lisans Tezi. Balıkesir Üniversitesi Sosyal Bilimler Enstitüsü, Balıkesir.

Özyürek, A. (2009). Okul öncesi eğitimi öğretmen ve yöneticilerinin iş doyumu, kişisel özellik ve mesleki değerlendirilmesi. Milli Ĕgitim Dergisi, 182, 8-21.

Sarıbay. E. ve Sarıbay. B. (2016). Bireysel demografik değişkenlerin iş doyumu ile olan ilişkisinin parametrik olmayan istatistiksel yöntemler ve faktör analizi ile incelenmesi üzerine bir araştırma. Akademik Sosyal Araştırmalar Dergisi, 4(30), 580-603.

Sharma, R. D. and Jyoti, J. (2009). Job satisfaction of university teachers: an empirical study. Journal Of Services Research, 9(2), 51-80. 
Silah, M. (2002). Sanayi işletmelerinde önemli ve çağdaş bir gereksinim: Süreç danışmanlığı uygulamaları. Çukurova Üniversitesi Sosyal Bilimler Dergisi, 26(1), 143-168.

Skaalvik, E. M. and Skaalvik, S. (2011). Teacher job satis faction and motivation to leave the teaching profession: Relationswith school context, feeling of belonging, and emotional exhaustion. Teachingand Teaching Education, 27, 1029-1038.

Tabak, I. and Argon, T. (2018). The teacher opinions on emotional labour and loneliness in the workplace. Journal of the Faculty of Education, 19(3), 01-13.

Tabancal1, E. (2016). The relationship between teachers' job satisfaction and loneliness at the workplace. Eurasian Journal of Educational Research, 16(66), 263-280.

Ünal, A. (2015). İ̧ doyumu, yaşam doyumu ve yaşam anlamı değişkenlerinin ilkokul ve ortaokul ögretmenlerinin mesleki bağlllıkları üzerine etkisi. Yüksek Lisans Tezi. Ondokuzmayıs Üniversitesi Eğitim Bilimleri Enstitüsü, Samsun.

Weiss, R., Dawis, G., England, G. and Andlofquist, L. (1967). Minnesota studies in vocational rehabilitation 22: Manual forthe Minnesota Satisfaction Questionnaire. Minneapolis: University of Minnesota.

Wright, S. (2005). Organizational climate, social support and loneliness in theworkplace. Research on Emotion in Organizations, Emerald Group Publishing Lim. 1, 123-142.

Wright, S. (2007). The experience of loneliness in organisations. https://ir.canterbury.ac.nz/handle/10092/1856

Yakut, S. ve Certel, H. (2016). Öğretmenlerde yalnızlık düzeyinin çeşitli değişkenler açısından incelenmesi. Birey ve Toplum Sosyal Bilimler Dergisi, 6(1), 69-94.

Yavuzkurt, T. (2017). Ortaöğretim öğretmenlerinin iş yeri arkadaşlık algısı ve iş doyumu ile ilişkisi (Aydın ili örneği). Yüksek Lisans Tezi. Adnan Menderes Üniversitesi Sosyal Bilimler Enstitüsü, Aydın.

Y1lmaz (2014). Özel okullardaki ilkokul müdürlerinin liderlik biçimi ile sinıf öğretmenlerinin iş doyumu arasındaki ilişki. Yüksek Lisans Tezi. Okan Üniversitesi Sosyal Bilimler Enstitüsü, İstanbul.

Yılmaz, A. ve Boğa Ceylan, Ç. (2011). İlköğretim okul yöneticilerinin liderlik davranış düzeyleri ile öğretmenlerin iş doyumu ilişkisi. Kuram ve Uygulamada Egitim Yönetimi Dergisi, 17(2), 277394.

Yukay Yüksel, M., Özcan, Z. ve Kahraman, A. (2013). Orta yaş öğretmenlerin yalnızlık düzeylerinin bazı değişkenler açısından incelenmesi. Ĕgitim ve Öğretim Araştırmaları Dergisi, 2(4), 277 285.

Yurcu, G. ve Kocakula, Ö. (2015). Konaklama işletmelerinde çalışan yalnızlığının öznel iyi oluş üzerine etkisi. Adnan Menderes Üniversitesi, Sosyal Bilimler Enstitüsü Dergisi, 2(1), 30-41. 


\section{Extended Abstract}

\section{Introduction}

It is known that job satisfaction has an impact on spiritual and physical health and on performance. Insufficient job satisfaction will obstruct an employee's psychologic maturity and might cause disappointment and decrease an employee's efficiency and performance. At the same time, it is believed that teachers' decreased loneliness at work can contribute to higher education and training quality, increase success, and create a good school environment. This study aims to determine classroom teachers' job satisfaction and work life loneliness level and thus contribute to precautions that could increase job satisfaction and decrease loneliness at work. This study is important because considering negative situations around job satisfaction and loneliness in work life and offering recommendations in favour of teachers will support and guide future studies.

\section{Method}

This study is quantitative, and a relational survey model was adopted during data collection. Convenience universe of this study consists of classroom teachers working in Kırşehir and Erzurum cities. The sample of this study consisted in total of 415 classroom teachers during the 2017-2018 academic year working in elementary schools in Kurşehir and Erzurum cities under the Ministry of Education. To easily access teachers in the study group, convenience sampling method was selected. In this study, "Personal Information Form" was used to collect data on teachers' personal characteristics; "Minnesota Job Satisfaction Scale" was used to analyse classroom teachers' job satisfaction level and "Loneliness in Work Life Scale" was used to analyse loneliness in work life. Obtained data were analysed with a package data program. While high scores from Minnesota Job Satisfaction Scale show job satisfaction, low scores show job dissatisfaction. Low score from Loneliness in Work Life Scale show low level of loneliness in work life.

\section{Findings}

Classroom teachers' job satisfaction total scores ranged between 34 and 100 and the average score was 79.67. When job satisfaction data were analysed, it is seen that $2.7 \%$ had low level job satisfaction, $37.1 \%$ had moderate level job satisfaction, and $60.2 \%$ had high level job satisfaction. When classroom teachers' job satisfaction average was considered, $\overline{\mathrm{X}}=76.67$ showed high level job satisfaction.

It is seen that classroom teachers' job satisfaction total scores showed no statistically significant difference for gender, marital status and experience.

Classroom teachers' loneliness in work life total scores ranged between 16 and 76 . When data for loneliness in work life are analysed, it is seen that $79.1 \%$ have low level, $19.5 \%$ have moderate level and $1.4 \%$ have high level loneliness in work life. When classroom teachers' loneliness in work life average is considered, $\overline{\mathrm{X}}=30.27$ shows low level loneliness in work life.

It is seen that classroom teachers' loneliness in work life total scores showed no statistically significant difference for gender and marital status. It was seen that classroom teachers' experience have significant difference with loneliness in work life total scores. $\left[\chi_{(5)}^{2}=17,16 ; p<0,05\right]$. After multiple comparison with Mann-Whitney $U$ test, this difference is identified between groups 1-2, 1-3, $1-4,1-5,1-6$ and 5-6.

It is determined that there is negative, strong and statistically significant relationship based on a Pearson correlation test conducted to determine the relationship between classroom teachers' job satisfaction score and loneliness in work life score $(r=-0,402, p<0,05)$. Based on these results, it can 
be stated that while classroom therefore' job satisfaction increased, loneliness in work life decreased; while job satisfaction decreased, loneliness in work life increased.

\section{Results and Discussion}

According to findings of this study, it is determined that classroom teachers' have a high level of job satisfaction. It can be stated that teachers seeing children they raised in different positions and status, and their students showing same the respect and protection can have an impact on increased job satisfaction level. It is found that that there is no statistically significant difference between classroom teachers' gender, marital status and experience and internal satisfaction, external satisfaction and job satisfaction.

Study findings show that classroom teachers experience low level emotional deprivation, social friendship and loneliness in work life. In general, it is believed that longer and stronger communication and interaction with students and parents compared to branch teachers decreased loneliness in work life. Based on the gender variable, it is found that there is statistically significant difference between classroom teachers' emotional deprivation and loneliness in work life; however, it is found that male teachers are lonelier in social friendship dimension compared to female teachers. Based on marital status dimension, it is seen that there is no statistically significant difference between classroom teachers' emotional deprivation, social friendship and loneliness in work life scores.

It is found that classroom teachers with 1-5 years occupational experience are lonelier in work life that other classroom teachers and classroom teachers with 26 years or more experience are lonelier in work life than classroom teachers with 21-25 years of experience. It can be said that low occupational experience and adaptation problems to new socio-cultural environment among 1-5 years of occupational experience and displacement and distance from friends due to other reasons among 26 years or higher occupational experience caused teachers to feel lonely on social friendship level.

It is found that there is negative and statistically significant relationship between classroom teachers' job satisfaction and loneliness in work life. In general, decreased loneliness in work life with increased job satisfaction is an expected result.

- In this study, quantitative methods are applied and qualitative or mixed methods can be applied to analyse job satisfaction and loneliness in work life in-depth in different dimensions.

- To increase teachers' job satisfaction and decrease loneliness in work life, the recommendations of this study include solving expectations and problems regarding employee personal rights.

- A fair reward and promotion system can be developed for teachers to increase satisfaction levels. 